\title{
Bone and Joint Infections: The Role of Imaging in Tailoring Diagnosis to Improve Patients' Care
}

\author{
Andrea Sambri ${ }^{1,2, *(\mathbb{D})}$, Paolo Spinnato ${ }^{3}\left(\mathbb{D}\right.$, Sara Tedeschi ${ }^{2,4}$, Eleonora Zamparini ${ }^{4}$, Michele Fiore ${ }^{2}(\mathbb{D}$, \\ Riccardo Zucchini ${ }^{2}$, Claudio Giannini ${ }^{2}$, Emilia Caldari ${ }^{1}$, Amandine Crombé ${ }^{5}$, Pierluigi Viale ${ }^{2,4}$ and \\ Massimiliano De Paolis ${ }^{1}$ (D) \\ 1 Orthopedics Unit, IRCCS Azienda Ospedaliero-Universitaria di Bologna, 40138 Bologna, Italy; \\ emilia.caldari@gmail.it (E.C.); Massimiliano.depaolis@aosp.bo.it (M.D.P.) \\ 2 DIMEC, University of Bologna, 40133 Bologna, Italy; sara.tedeschi@unibo.it (S.T.); michele.fiore@ior.it (M.F.); \\ riccardo.zucchini@ior.it (R.Z.); claudio.giannini@ior.it (C.G.); pierluigi.viale@unibo.it (P.V.) \\ 3 Radiology Unit, IRCCS Istituto Ortopedico Rizzoli, 40136 Bologna, Italy; Paolo.spinnato@ior.it \\ 4 Infectious Disease Unit, Azienda Ospedaliero-Universitaria di Bologna, 40138 Bologna, Italy; \\ Eleonora.zamparini@aosp.bo.it \\ 5 Department of Oncologic Imaging, Institut Bergonié, Comprehensive Cancer Center of Nouvelle-Aquitaine, \\ 33000 Bordeaux, France; a.crombe@bordeaux.unicancer.fr \\ * Correspondence: andrea_sambri@libero.it
}

\section{check for} updates

Citation: Sambri, A.; Spinnato, P.; Tedeschi, S.; Zamparini, E.; Fiore, M.; Zucchini, R.; Giannini, C.; Caldari, E.; Crombé, A.; Viale, P.; et al. Bone and Joint Infections: The Role of Imaging in Tailoring Diagnosis to Improve Patients' Care. J. Pers. Med. 2021, 11, 1317. https://doi.org/10.3390/ jpm11121317

Academic Editors: Niels Bergsland and Pierluigi Maria Rinaldi

Received: 18 September 2021

Accepted: 2 December 2021

Published: 7 December 2021

Publisher's Note: MDPI stays neutral with regard to jurisdictional claims in published maps and institutional affiliations.

Copyright: (c) 2021 by the authors. Licensee MDPI, Basel, Switzerland. This article is an open access article distributed under the terms and conditions of the Creative Commons Attribution (CC BY) license (https:// creativecommons.org/licenses/by/ $4.0 /)$.

\begin{abstract}
Imaging is needed for the diagnosis of bone and joint infections, determining the severity and extent of disease, planning biopsy, and monitoring the response to treatment. Some radiological features are pathognomonic of bone and joint infections for each modality used. However, imaging diagnosis of these infections is challenging because of several overlaps with non-infectious etiologies. Interventional radiology is generally needed to verify the diagnosis and to identify the microorganism involved in the infectious process through imaging-guided biopsy. This narrative review aims to summarize the radiological features of the commonest orthopedic infections, the indications and the limits of different modalities in the diagnostic strategy as well as to outline recent findings that may facilitate diagnosis.
\end{abstract}

Keywords: bone infections; prosthesis infections; diagnosis; imaging

\section{Introduction}

Bone and joint infections (BJI) are a major problem because of important social and financial problems [1,2]. The incidence is assessed to be approximately 70/100,000 patients/year and increases with age [3]. Orthopedic infections represent an extremely heterogeneous group of diseases that require complex medical care, including implantassociated infections (e.g., prosthetic joint infections and infections after fracture fixation), septic arthritis, and osteomyelitis. Numerous operations and long-term antimicrobial treatment are generally necessary to treat infection and restore function.

Imaging is of paramount importance to confirm the diagnosis, establish the gravity and degree of infection, plan biopsy and control the response to therapy. The clinical diagnosis is often uneasy due to the nonspecific symptoms, making imaging crucial to plan patients' management. Some radiological features are pathognomonic of bone and joint infections for each modality used. However, imaging diagnosis of these infections can be challenging as well, because of several overlaps with non-infectious etiologies. In parallel, these last two decades have shown innovations in quantitative imaging that could provide new clues towards adequate diagnosis, from new contrast media, nuclear tracer to improved imaging post-processing and quantification.

Interventional radiology is generally needed to confirm the diagnosis and to detect the microorganism responsible for the infection through imaging-guided biopsy. 
This narrative review aims to summarize the radiological features of the commonest orthopedic infections, the indications and the limits of the different modalities in the diagnostic strategy as well as to recap recent findings that may facilitate diagnosis.

\section{Acute Osteomyelitis}

Osteomyelitis (OM) is a bone inflammation caused by infection. Acute OM can be secondary to hematogenous spread or to direct inoculation by trauma, contiguous or post-operative infection [4]. In the late stages, diagnosis can be easily achieved clinically. However, an early accurate diagnosis is more challenging, and it often necessitates multiple imaging techniques [5].

Radiographs. Radiographs are the first study indicated when acute OM has been supposed [6,7]. Destruction of cortical bone, permeative marrow lucency, and periosteal reaction can be observed on x-rays in the case of acute OM [8]. Other suggestive signs include joint space widening and soft tissues alterations (swelling, gas, foreign body) (Figure 1A,E). A reduction of $30 \%$ to $50 \%$ in bone density is required before the radiographic change is apparent. Thus, the sensitivity and specificity of $\mathrm{x}$-rays to detect acute OM and bone findings are relatively low, in particular during the first 10-14 days of infection [9].

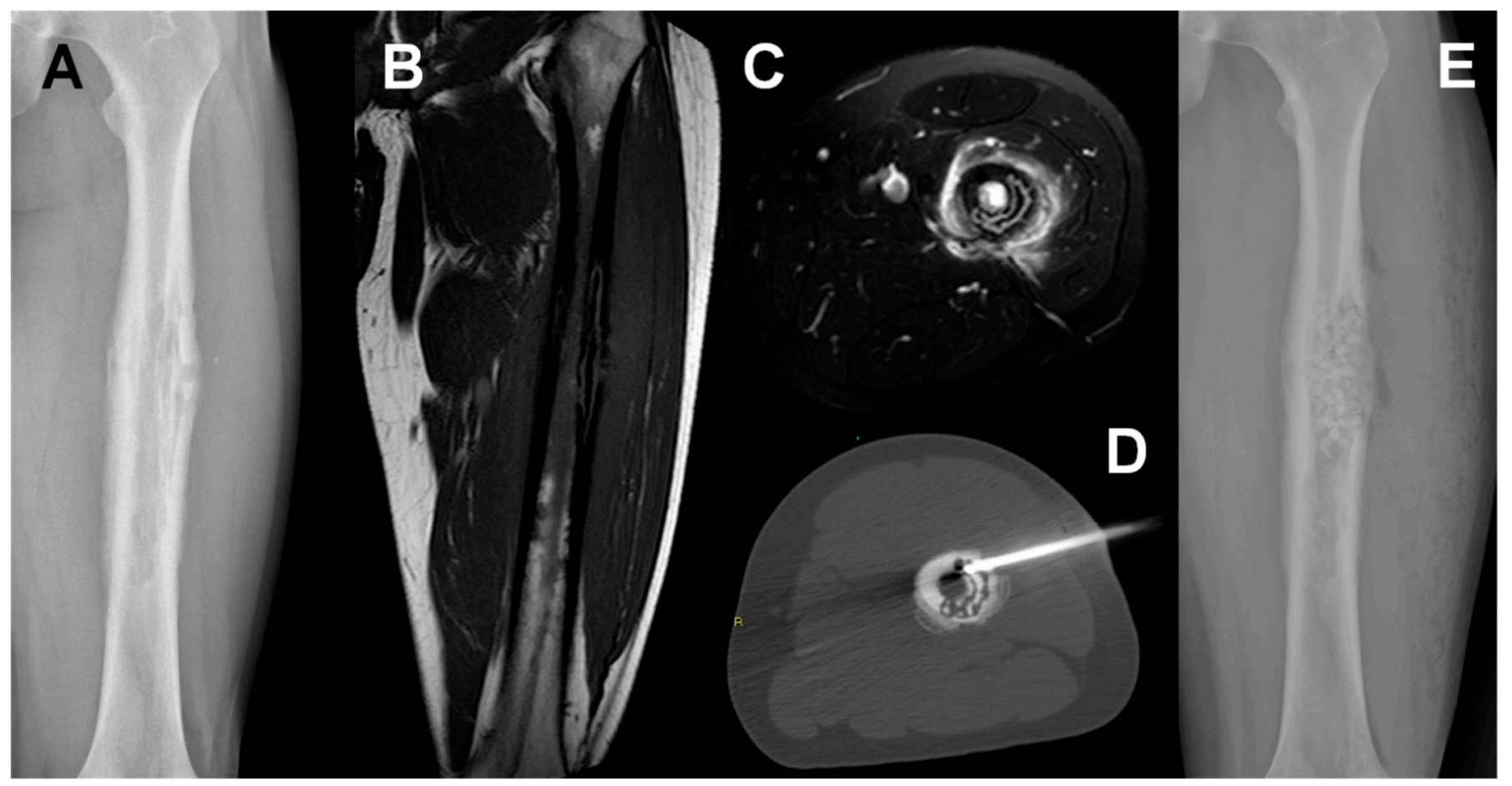

Figure 1. Staphylococcus aureus Osteomyelitis in a 20-year-old man. A conventional radiograph (A). MRI coronal T1w (B) and axial T2w fat-saturated (C) show a permeative lesion of the left femoral shaft. CT-guided biopsy permitted to identify the responsible microorganism (D). Conventional radiograph after surgical treatment showed antibiotic microspheres placed into the bone (E).

Ultrasound (US). US represents a non-invasive technique to assess soft tissues and cortical bone; it can guide diagnostic aspiration, drainage, or tissue biopsy. Ultrasound is rapid, low-cost, and does not expose the patient to radiation. However, it largely depends on the operator. Moreover, the permeation and wave reflection can be impeded by gas (intestine) or dense structures (bone), making deep tissue difficult to visualize. US may identify signs of OM earlier than X-rays [10], in particular in children [11]. Periosteal reaction is major in the immature skeleton, principally in long bones [12]. The initial signs of acute OM on the US are juxtacortical swelling of soft tissues and periosteal elevation or thickening. The periosteal abscess must be supposed if a hypo- to hyperechogenic alteration adjacent to the bone surface with adjacent structure dislocation is shown. 
Computed tomography (CT). CT provides an optimal characterization of cortical bone destruction and periosteal reaction and offers information regarding soft tissue alterations. It is the best technique to detect small foci of gas inside the medullary canal, an uncommon but consistent sign of OM [13] and zones of cortical erosion [14]. It may help to definite the area of the infection, particularly in regions of complex anatomies, such as the spine, and to guide interventional procedures (biopsies and aspirations), particularly in the vertebral column and sacroiliac joints (Figure 1D). Post-contrast CT can help to identify soft tissue abnormalities.

Magnetic resonance imaging (MRI). MRI is highly sensitive to detect $\mathrm{OM}$ in the first 3-5 days (Figure 1B,C) [15]. Moreover, it provides more accurate information regarding the extent of bone involvement when the diagnosis OM has already been formulated. The most appropriate sequences to detect acute $\mathrm{OM}$ are the short tau inversion recovery (STIR) and the T2-weighted imaging (WI) fat-suppressed fast spin-echo (SE) sequences [16]. Edema and exudates within the medullary space produce a low-signal intensity on the T1- weighted images and a high signal on T2 WI and STIR or fat-suppressed sequences. Soft tissues are frequently altered as well, with ill-defined planes. The cortical bone can be interrupted and can have abnormally amplified signal intensity. The absence of cortex thickening helps to differentiate acute from chronic OM [17]. Gadolinium-enhanced sequences help to outline zones of necrosis [15] and are useful to detect abscess [18]. Sinus tracts can extend from the marrow and bone, through the soft tissues, out the skin as high signal intensity spaces on T2-WI [19]. MRI can also help to plan treatment, particularly, percutaneous drainage of fluid collections and surgical debridement. MRI allows to assess the extent of necrotic tissue and to define the dangerous contiguous structures (spine, physes, and joint space), which need customized management to avoid morbidity and complications.

Whole-body (WB)-MRI combines optimal anatomical resolution with the ability to complement the exploration with functional-molecular qualitative and quantitative information via diffusion-weighted imaging (DWI), from nearly the entire body $[20,21]$. The excellent soft-tissue detail can help in identifying the targets for the collection of microbiological samples from the active areas.

Nonetheless, MRI has several disadvantages. First of all, the acquisition time is long (ranging from 20 to $90 \mathrm{~min}$ depending on the machine, sequences protocols, region of interest, and contrast media administration). Thus, patients with a painful disease and/or poor clinical conditions, as well as children, should require other examinations (e.g., CT or PET-CT) or receive sedation/pain therapy before MRI [22,23].

Moreover, MRI is an expensive tool (like PET-CT), and its availability varies depending on geographic areas.

Metal implants should contraindicate MRI because of the presence of ferromagnetic materials, or just reduce the image quality because of metal artifacts. Anyway, several recent improvements (new techniques able to reduce metal artifacts) rendered this issue less problematic [24].

Nuclear medicine. The diagnosis of OM can remain doubtful and radionuclide imaging is commonly comprised in the diagnostic work-up. The bone scan is usually positive within 24 to $48 \mathrm{~h}$ after the onset of symptoms [25]. Currently, the use of nuclear medicine examination in the diagnostic strategy depends on the pre-test clinical probability for OM. Bone scintigraphy (BS) is helpful to exclude infection when there is a low probability of $\mathrm{OM}$, thanks to its high negative predictive value, especially in a non-operated or recently fractured bone.

Three-phase BS (arterial, venous, and bone phases) is typically performed with diphosphonates marked with Technetium-99 m (99 mTc). Their uptake varies on the blood flow, osteoblastic activity, and calcium deposits. OM is diagnosed when there is a focal increase in bone activity in the area of interest on delayed imaging. Furthermore, the positivity on the three phases is highly sensitive for OM (73-100\% sensitivity). On the contrary, a normal BS on the three phases almost completely rules out OM due to its high negative 
predictive value. However, BS lacks specificity (44.6\%) and shows overlaps with noninfectious processes (fractures, inflammatory or degenerative osteoarthritis) [26]. Moreover, arterial and venous phases of BS are generally negative in the case of low-grade infection. Increased uptake on the first two phases but not on the third phase can be also observed in patients with soft tissue infection without OM.

Scintigraphy with gallium citrate $\left({ }_{67} \mathrm{Ga}\right)$ can be obtained in combination with a Tc scan. The combined information may be more helpful than each examination alone [27]. The role of ${ }_{67} \mathrm{Ga}$ scintigraphy is restricted nearly exclusively to the vertebral column.

In patients with a recent fracture or recent surgery, labeled leukocyte scintigraphy (LLS) is the first choice [28]. LLS is usually executed with either ${ }_{111}$ In oxyquinolone (In) or $99 \mathrm{mTc}$-exametazime. It is less beneficial for infections where the principal cellular response is not neutrophilic (i.e., tuberculosis) [29].

In addition to these traditional radionuclide imaging procedures, positron-emitting radiopharmaceuticals, including fluorodeoxyglucose (FDG) and ${ }_{68} \mathrm{Ga}$ show promising results [30]. Fusion imaging techniques (combined single-photon emission computed tomography with CT (SPECT/CT) and positron emission tomography with CT (PET/CT)) resulted in significant improvements. These fusion imaging techniques can help in the discrimination between soft tissue and bone infection by providing morphological information. PET is a tomographic technique that allows accurate localization of radiopharmaceutical accumulation. FDG stores in almost all leukocytes and its uptake is associated with their metabolic speed and the number of glucose transporters [31].

The positron-emitting gallium isotope $\left({ }_{68} \mathrm{Ga}\right.$ ) has benefits over ${ }_{67} \mathrm{Ga}$ for diagnosing $\mathrm{OM}$. The half-life of ${ }_{68} \mathrm{Ga}$ is much shorter than that of ${ }_{67} \mathrm{Ga}(68 \mathrm{~min}$ and $78 \mathrm{~h}$, respectively), which allows for the administration of greater amounts of radioactivity. Imaging is executed within a few hours after inoculation, whereas ${ }_{67} \mathrm{Ga}$ imaging is executed 1-3 days after inoculation [32].

The use of sodium fluoride positron emission tomography (18F-NaF PET/CT) has recently been shown to be a useful tool. Following the guidelines from the European Association of Nuclear Medicine (EANM), this tool is indicated in patients with suspected or proved osteomyelitis [33].

However, none of these radiopharmaceuticals is equally efficacious in all body regions. The selection of the appropriate examination should be determined by experts depending on the clinical question and the anatomical setting [30].

Some studies have deemed MRI superior to ${ }^{18} \mathrm{~F}$-FDG-PET/CT [34], in particular in zones where detailed structural data [35] or distinction among benign and malignant bone marrow lesions is necessary. Other series observed that the addition of ${ }^{18}$ F-FDG PET/CT to MRI has a specific ability to discriminate degenerative alterations from OM [36]. Hybrid PET/MRI scanners have also been developed, but they are very costly. Thus, it looks well to use MRI as the primary imaging tool for simple cases, whereas PET should be done when there is a (possible) multifocal disease or a contraindication for MRI [37].

\section{Septic Arthritis}

Septic arthritis (SA) is an emergency since it can lead to quick joint destruction and irreversible loss of function within $24-48 \mathrm{~h}$, with a high mortality rate (10-50\% in adults).

SA can be hematogenous or come from direct injection of the bacteria in the joint. It can also come from the adjacent spread of OM to the articular surface.

Radiographs. Bone erosions, joint space loss, periarticular osteopenia, and soft tissue swelling can be observed on $x$-rays. In the case of $\mathrm{OM}$, variations in bone signal on both sides of a joint are suggestive of SA. However, radiographs are insensitive, as these signs may be delayed, particularly in non-pyogenic infections. In the beginning, the surrounding soft tissues increase in size, and pseudo widening emerges in the joint interline due to capsule-synovial tumefaction and effusion (Figure 2A). 


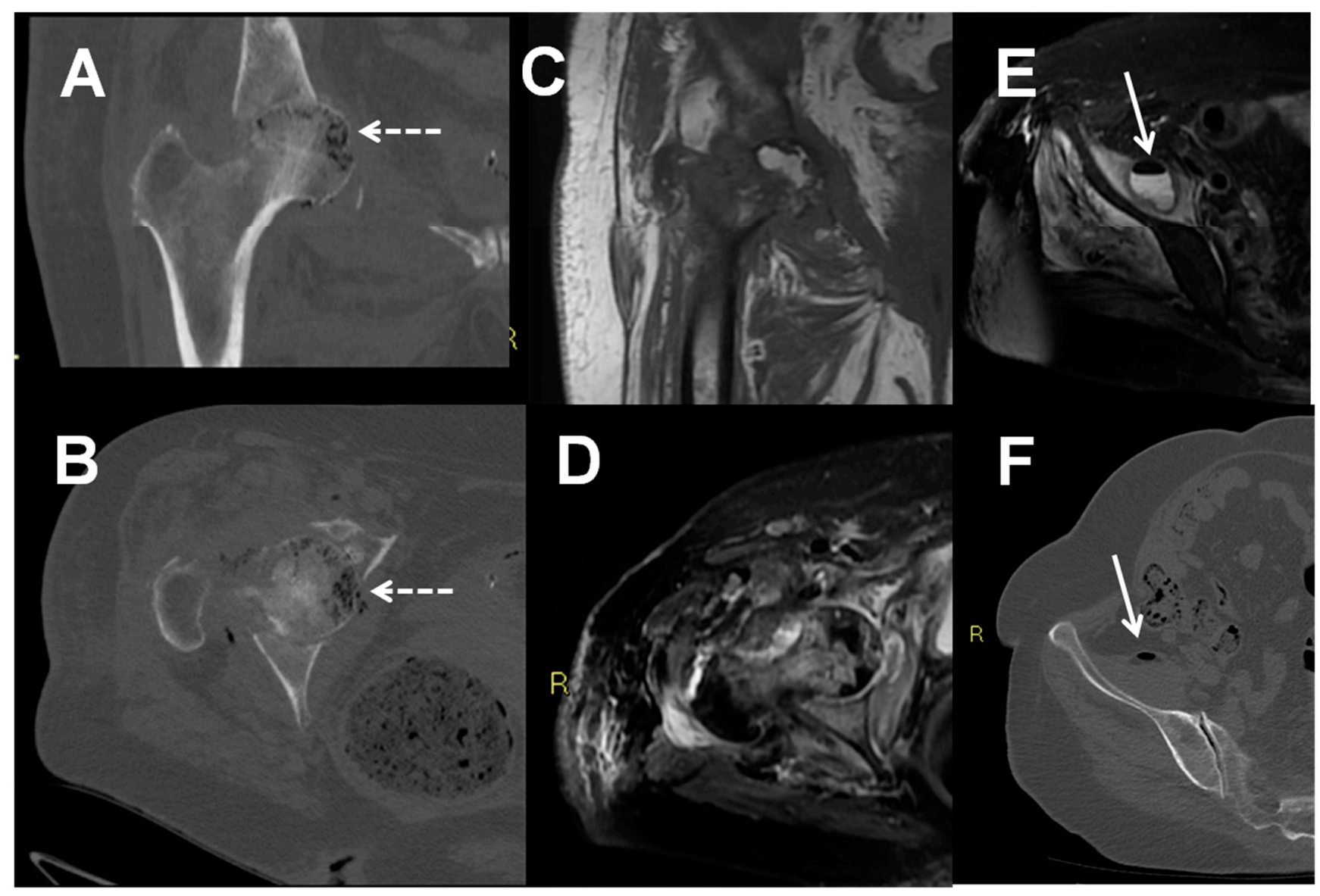

Figure 2. Septic arthritis of the right hip in a 78 years old woman with studied with x-rays (A), CT (B,F), and MRI $(\mathbf{C}, \mathbf{D}, \mathrm{E})$. CT showed bone intramedullary air coefficients (broken arrows) and involvement of the homolateral ileo-psoas muscle (arrows).

Ultrasonography. US can be helpful to differentiate SA from OM, particularly in the case of hip SA [15]. Lack of a joint effusion has a high negative predictive value for SA [38], while if an effusion is observed it can be either SA or other inflammation of the joint. Power Doppler might help, highlighting the presence of synovial and soft tissue hyperemia [39].

Computed tomography. CT is beneficial in particular in SA of fibrocartilaginous joints (pubic symphysis, sacroiliac, or sternoclavicular) and events of concomitant OM (Figure 2B,F).

Magnetic Resonance Imaging. MRI is very sensitive to diagnose SA in native hips, with characteristic discoveries of joint effusion, synovial thickening/synovitis, erosions, and periarticular soft-tissue edema [40] (Figure 2C-E). However, specificity can be slightly low, as any inflammatory process of the joint can have an analogous manifestation. MRI findings comprise joint effusion with enhancing synovitis, cartilage thinning, bone erosions, and periarticular soft-tissue edema [41]. Subperiosteal fluid collections can be observed with low signal intensity on the T1-weighted sequences and with intermediate to high signal intensity on the T2 and fat-suppressed images.

Nuclear Medicine. Radionuclides studies have a partial role to diagnose SA. It can differentiate OM from soft-tissue infection and detect multifocal joint infections. All three phases of bone scintigraphy show more uptake of the radionuclide due to hyperemia in the synovial vessels [42].

The role of ${ }_{18} \mathrm{~F}$-FDG PET/CT has not been defined yet [43] because ${ }_{18} \mathrm{~F}-\mathrm{FDG}$ accumulates also in inflammatory arthritis, similarly to gallium and labeled leukocytes. 


\section{Chronic Osteomyelitis}

Osteomyelitis can be classified based on the onset of symptoms (acute OM within two weeks, subacute OM within one to several months, and chronic OM after a few months). Progression to chronic OM is depicted by periosteal reaction, cortical thickening, and the presence of avascular bony fragments (sequestrum) [44].

Radiographs. Chronic OM usually appears on $\mathrm{x}$-rays as sclerosis and cortical thickening adjacent to lytic zones within the marrow (Figure 3A) [8]. A lucent sinus tract may be detectable.

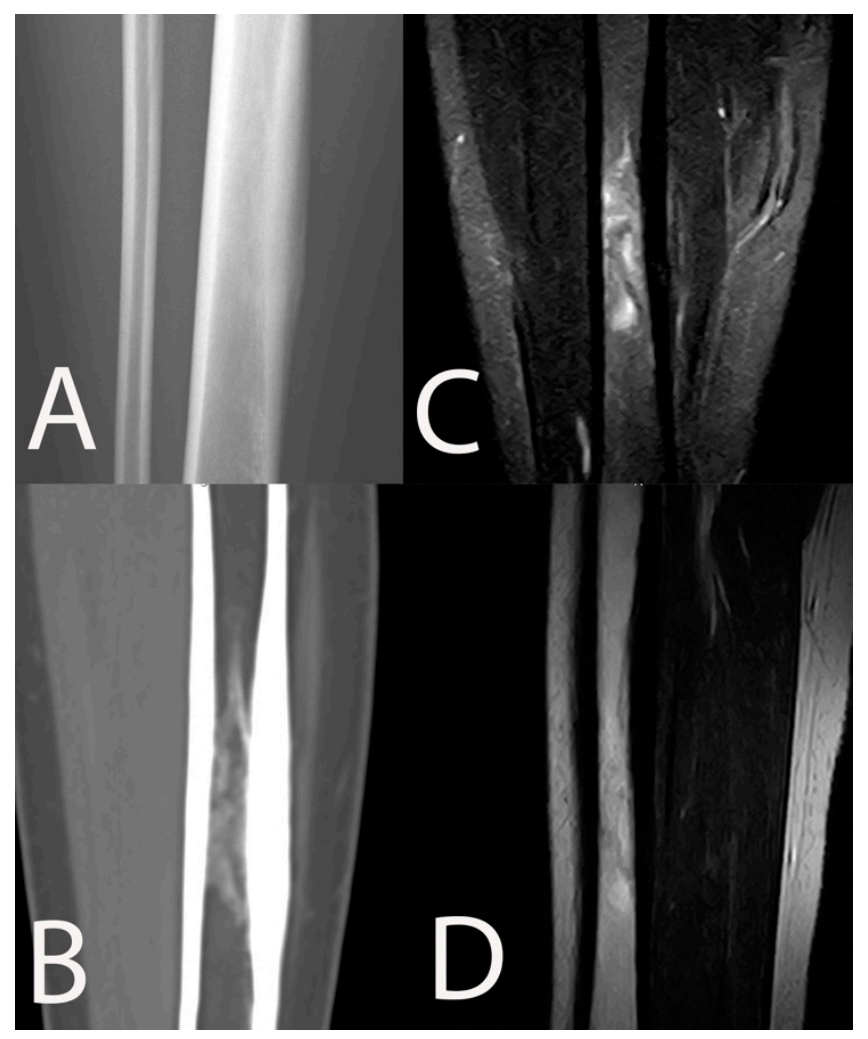

Figure 3. Chronic osteomyelitis of the tibia in a 16-year-old female. Periosteal reaction and sclerotic intramedullary focus are detectable on conventional radiography (A) and CT scan (B). MRI showed ill-defined bone edema among the sclerotic intramedullary changes on STIR coronal (C) and T1w sagittal (D).

Ultrasonography. US can aid to evaluate a chronic OM recrudescence that can associate with soft tissue abscess, fistula, or sinus tract [45]. Soft tissue abscess in chronic OM is recognized as a hypo- or anechoic fluid collection.

Computed tomography. CT exhibits anomalous inspissation of the affected cortical bone, with sclerosis, invasion of the medullary cavity, and an atypical chronic draining sinus [35] (Figure 3B). The major role of CT in chronic OM is the detection of sequestrum. These fragments of avascular bone can be masked by the adjacent osseous abnormalities on standard X-rays.

Wu et al. [46] recently proposed a machine learning algorithm based on CT scans which exhibited encouraging performances (sensitivity $88.0 \%$, specificity $77.0 \%$ ) and higher than serum biomarkers such as CRP, ESR, and D-dimer for chronic, post-traumatic OM of the limbs.

Magnetic resonance imaging. On MRI, the sequestrum looks like a low-signal area within a granulation tissue inside the bone marrow displaying high signal intensities on T2-WI [47]. Linear high signal intensities on T2-WI which extend across the involucrum correspond to the cloaca, which is a tract leading out of the bone from the medullary cavity. 
Periostitis can create a border of high signal intensity on T2-WI encompassing the outer surface of the cortex (Figure 3C,D).

Contrast-enhanced T1-WI is essential to localize the sequestrum, as it does not show post-contrast enhancement. The pattern of contrast enhancement can permit the discrimination of fibrovascular scar from infectious foci, facilitating to discern between acute and chronic OM [48].

Squamous cell carcinoma of the sinus tract is an unusual complication of long-lasting chronic OM, which occurs in $0.23 \%$ to $1.6 \%$. It can be identified on MRI as an anomalous soft tissue lump [49].

Nuclear medicine. PET and SPECT are very precise procedures to assess chronic OM, which allow to differentiate it from soft tissue infections. FDG PET/CT has the highest performances (sensitivity $94 \%$, specificity $87 \%$ ) to confirm or exclude the diagnosis of chronic OM compared to MRI, BS, or LLS, especially in the axial skeleton [50,51].

\section{Brodie's Abscess}

Brodie's abscess is a sub-acute form of OM, frequently with an insidious onset, which displays as a collection of pus in the bone [52]. It is an infection delimited inside the myelum, surrounded by a sclerotic wall, thus minimizing the systemic inflammatory response. It is best detected by the combination of standard x-rays and MRI [53].

Radiographs. Brodie's abscess can have an inconstant look, but it normally looks like a lytic unicameral or multiloculated lesion with a sclerotic rim that is oriented along the long axis of the bone. It is bordered by a thick dense rim of reactive sclerosis that disappears into contiguous bone. A concomitant minor periosteal reaction can be present. The lesion diameter ranges from $4 \mathrm{~mm}$ to $5 \mathrm{~cm}$.

Computed tomography. Central osteolysis on CT scan with thick rim ossification may be observed, with extensive thick, well-circumscribed periosteal reaction and bone sclerosis around the lesion (Figure 4).

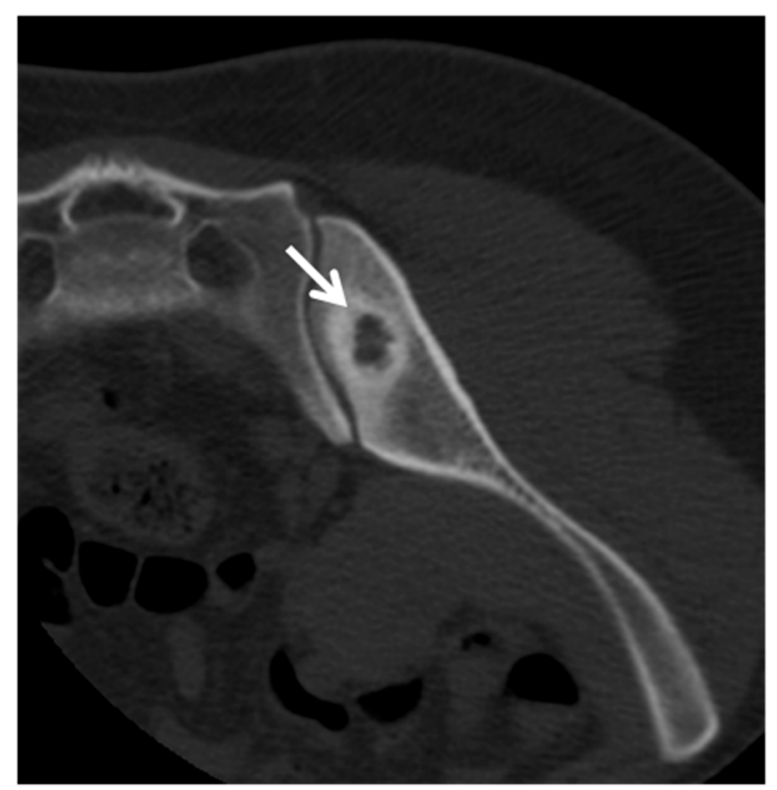

Figure 4. Brodie's abscess in a 30-year-old man. Computed tomography of the pelvis showed a small $(1.5 \mathrm{~cm})$ radiolucent lesion with thick and irregular sclerotic margins (arrow).

Magnetic Resonance Imaging. Brodie's abscess is visible on MRI as a so-called "target sign", which is formed by four concentric layers of tissue (necrotic tissue at the center, encircled by an adjacent deposit of granulation tissue, and sclerotic or fibrotic tissue with an outermost rim of edema). Starting centrally and moving outward, this results in T1weighted sequences in a pattern of low signal (necrosis), intermediate (isointense to muscle) signal (granulation tissue), very low signal (sclerotic or fibrotic tissue), and low signal 
(edema). On T2 sequences, a pattern of high, intermediate-high, low, and high signal intensities can be appreciated, respectively [54]. Only a peripheral ring enhancement is appreciated after gadolinium administration [55].

Nuclear Medicine. Scintigraphy generally shows high activity. Active FDG lesions have been reported in a few reports [56,57]. However, the function of nuclear medicine in the diagnosis of Brodie's abscess is still debated, and it needs further investigation.

\section{Diabetic Foot Osteomyelitis}

Diabetic foot OM generally comes from contiguous soft tissue ulcers. It is more frequent near the fifth and first metatarsophalangeal joints. The global prevalence of diabetic foot is $6.4 \%$ [58]. It can be confused with the rarer Charcot arthropathy (prevalence $0.1 \%$ ): the damage of osteoarticular structures of a foot on a neuropathic basis but with no infection [59]. In the evaluation of OM, infection focus should be searched close to the ulcer [60].

Radiographs. The soft tissues should be assessed for a lucent defect at the skin surface. Foci of air may commonly be found spreading from the ulcer to the infected bone [61]. The bone should be evaluated for cortical erosion and focal osteopenia.

Computed Tomography. CT can assess periosteal reaction, cortical loss, and changes in bone marrow density [62].

Magnetic Resonance Imaging. The Infectious Disease Society of America guidelines recommends MRI to diagnose diabetic foot OM, even though bone biopsy with histopathology and microbiology is the "gold standard" [63,64]. Sensitivity and specificity of MRI for the early diagnosis of diabetic foot $\mathrm{OM}$ are $90 \%$ and $79 \%$, respectively [65]. However, MRI displays low specificity and positive predictive value when there are non-infectious changes, especially in patients with previous foot surgery, trauma, or Charcot arthropathy $[66,67]$.

On MRI diabetic foot OM is characterized by a high signal on T2-WI and STIR and signal on T1-WI [40,68]. However, when isolated, T2 hyperintensity or bone marrow edema is observed with no confluent intermediate T1 signal, and it is defined as "osteitis". A T2 hyperintensity signal adjacent to a foot ulcer requires strict observation as it might become osteomyelitis in $>50 \%$ of the patients [69].

Nuclear Medicine. Treglia et al. [70] observed that FDG PET and PET/CT have high specificity, with increased usefulness if combined with MRI. White blood cell PET/CT is the nuclear test of choice [71] whereas the role of FDG is still to be established for diabetic foot OM [72].

Limited three-dimensional resolution is a weakness of nuclear medicine. The vascular disease which predisposes patients to extremity OM can limit the distribution of isotopes distally [73].

\section{Prosthetic Infections}

Prosthetic joint infection (PJI) must be ruled out in any patient with a painful joint prosthesis [74]. Differential diagnosis between infection and aseptic loosening is essential because the treatment of these two complications is different.

Diagnostic criteria which include clinical examination, laboratory tests, and X-rays represent initial evaluation. C-reactive protein, (CRP), ESR, and leukocyte count are not adequately sensitive or specific. Articular aspiration, albeit specific, has a variable sensitivity [28].

The initial radiological assessment of implant infection is radiographic. X-rays and $\mathrm{CT}$ can exclude other potential causes of failed prosthesis (periprosthetic fracture, dislocation, breakage of prosthesis components, and aseptic loosening). They can also identify periosteal new bone formation, which is considered a specific feature of PJI, although with low sensitivity $(16 \%)$ in early cases [75].

Radiographs. X-rays signs of PJI include sclerosis, periosteal reaction/cortical thickening, soft tissue gas, and component loosening. However, many of these can be seen also in aseptic loosenings. Thus, they are neither sensitive nor specific for PJI. Exuber- 
ant periosteal reaction and rapid radiographic progression are more suggestive of PJI [76]. Radiolucency along the metal-bone or cement bone interface that measures greater than 2 $\mathrm{mm}$ in width is another important abnormal finding [77].

Ultrasonography. Van Holsbeeck et al. [78] observed that US distention of the pseudocapsule greater than $3.2 \mathrm{~mm}$ was $100 \%$ sensitive and $74 \%$ specific for PJI. It was $100 \%$ specific for the diagnosis of PJI if combined with an extracapsular fluid collection. On the other hand, Weybright et al. [79] confirmed that although US is effective for the diagnosis of extracapsular fluid collections, it is not precise for diagnosing joint effusions. Moreover, the US can help in demonstrating fluid collection or sinus tracts in the soft tissues [80].

Computed tomography. CT is not normally useful for the diagnosis of PJI, since artifacts reduce image resolution $[75,81]$. It can detect focal and non-focal areas of periprosthetic osseous reabsorption. Periostitis was reported to be a specific (100\%) sign of infection, even if not sensitive [75]. Isern-Kebschul et al. [82] proposed the assessment of multiple parameters on $\mathrm{CT}$ as a useful diagnostic method in patients with suggestive symptoms of complications after total hip arthroplasty.

Magnetic Resonance Imaging. MRI is costly and time-consuming compared with CT. It has limited usefulness to evaluate small periprosthetic osteolysis and the position of the prosthetic components. It is not useful to guide joint aspiration or tissue biopsy. Metal arthroplasty components distort the magnetic field, resulting in a well-known imaging artifact called magnetic susceptibility. This can limit visualization of the periprosthetic bones and soft tissues, which has historically limited MRI utility in the evaluation of these patients. However, numerous new MRI systems have been introduced recently to reduce metal artifacts and ameliorate the visualization of bones and soft tissues adjacent to a metal implant [83-85].

MRI features in PJI generally comprise pericapsular soft-tissue edema, extracapsular collections, bone destruction, reactive lymphadenopathy, and joint effusion with debris and thick hyperintense synovium formed of multiple layers. The existence of periosteal reaction, capsule edema, and intramuscular edema after hip arthroplasty at $1.5 \mathrm{~T}$ MRI with metal artifact reduction have a high accuracy to evaluate PJI [84]. However, one positive MRI sign, such as periosteal reaction, is not specific for hip PJI [86].

Some papers reported high sensitivity and specificity of lamellated hyperintense synovitis as an MRI characteristic of PJI in patients with knee [87,88] and hip [89] prosthesis. Lamellated hyperintense synovitis in an MRI image refers to the thickened synovial tissue nearby the joint in MRI, and "high signal" refers to the high signal in the T2WI sequence image. Albano et al. [86] suggested that the evaluation of lymph node size and number between the affected and unaffected sides may improve the diagnosis of PJI in THA.

Nuclear Medicine. The initial radionuclide test made is generally BS. It is mainly used to rule out PJI because of its high sensitivity, but it has low specificity (even lower $-35 \%$ - in post-traumatic patients) [90]. In particular, the diagnostic reliability of BS is low in the first two years after prosthesis implantation. A positive BS does not confirm PJI, because it can also be positive because of another underlying bone disease or surgical intervention [91]. The diagnosis of PJI can be excepted with a negative BS. However, in the case of a positive BS, the addition of LLS significantly rises the diagnostic reliability for PJI, being useful in the differential diagnosis between PJI and reactive changes and/or aseptic loosening. In the case of a negative LLS, the probability of PJI is low [92].

PET/CT offers valuable information to evaluate a suspected PJI, regardless of which radiopharmaceutical is used $[93,94]$. It precisely localized abnormal white blood cells uptake, differentiating PJI and soft-tissue infection and providing information about the presence and the extent of infection. ${ }_{18}$ FDG PET/CT has a higher sensitivity (probably due to the subacute or chronic nature of most PJI, commonly involving monocytes and lymphocytes) but lower specificity than LLS $[95,96]$. For diagnosis, the site of the augmented uptake looks to be more important than its intensity (SUV), and uptake due to metallic artifacts should be taken into account [97]. Nonetheless, after surgery or trauma, ${ }_{18}$ FDG-PET must be avoided for 3 to 6 months to decrease the risk of false positive results [98]. 
When infection is suspected, LLS with 99mTc-hexamethyl propylene amine oxime or exametazime is the nuclear exam of choice in the first years after prosthesis implantation or after a non-conclusive BS [99]. A study without leukocyte uptake supports the absence of infection; weak uptake which reduces over time suggests inflammation (or aseptic loosening of prosthesis), whereas a leukocyte uptake which progressively intensifies and/or extends suggests PJI.

\section{Fracture Related Infection (FRI)}

Fracture-related infection (FRI) is an infection that occurs in the presence of a fracture [100]. This includes early infection around fracture implants, infected non-unions, hematogenous infections arising after fracture healing, and infections in fractures with no internal fixation [101]. When FRI is suspected, imaging is necessary to evaluate fracture consolidation and implant stability, confirm the infection, and assess the extent of the infection with specific anatomical details for surgical planning [100].

Radiographs. Although plain radiograph shows low sensitivity and specificity for the diagnosis of FRI [102], it is the first investigation of choice to judge implant positioning, fracture reduction, and osseous healing $[8,102]$. X-rays are also important to assess the progress of fracture consolidation and disease evolution by follow-up examinations [103].

Similar to OM, signs of acute infection include soft tissue swelling, periosteal reaction, and intraosseous abscesses $[8,102,103]$. Chronic infectious features comprise a sequestrum, involucrum, and elevation of the periosteum [8,103], whereby all osseous changes are much better localized and earlier detected with CT $[103,104]$.

Computed tomography. CT may also detect intra-medullar gas, which is considered a reliable sign of acute infection and allows a more detailed judgment of fracture consolidation $[8,103]$.

Magnetic Resonance Imaging. MRI has an excellent sensitivity to detect FRI (82-100\%) [104]. It identifies bone marrow edema as early as 1-2 days after onset of infection and soft tissue changes (such as abscesses, fistulae) [8]. With artifact reduction techniques, the interference of metal implants can be reduced to a minimum [105]. The downside of MRI is that its specificity is reduced probably because of its inability to differentiate between sterile inflammation, normal bone healing, and infected tissue (43-60\%) [104].

Nuclear Medicine. Nuclear imaging is far more accurate in cases where it is important to distinguish infected from non-infected tissues. Three-phase BS is highly sensitive for detecting FRI (89-100\%), but it has very low specificity (0-10\%) [104], thus being obsolete for this indication.

For suspected FRI less than 2 years after fracture fixation, the nuclear methods of choice are the LLS $[102,103,106]$, in which own white blood cells are labeled ex vivo with Indium-111 or Tc99m-HMPAO [102] and then re-injected. LLS + SPECT/CT is slightly more accurate (sensitivity 79-100\% and specificity 97\%) [91] than ${ }_{18}$ FDG-PET/CT (sensitivity $88-89 \%$ and specificity $76-80 \%$ ) [107]. However, although less accurate, ${ }_{18}$ FDG-PET has major advantages over LLS in terms of lower complexity of the labeling procedure, the requirement for just one scan, rather than early and late phase scans (over $20 \mathrm{~h}$ ), and its higher spatial resolution (3-4 mm vs. $8 \mathrm{~mm}$ ) [106]. In addition, LLS is not appropriate in patients who have recently been on antibiotics [108].

Nonetheless, despite extensively available data on nuclear imaging in OM in general, there is a lack of studies exclusively focusing on FRI. Therefore, there is a need for future randomized controlled trials on optimal diagnostic strategies for FRI [109,110].

\section{Spondylodiscitis}

The majority of Infectious spondylodiscitis (SD) is the consequence of hematogenous seeding of the subchondral bone with extension to the intervertebral disc. It can also come from a prior operation or extension of an adjacent soft tissue infection [111]. The diagnosis of SD is often a challenge. Imaging is necessary for the diagnosis, localization of the infection and definition of its extension, identification of an appropriate region to perform a 
biopsy, assessment of neurological and infectious complications, and evaluation of response to treatment. Imaging assessment of patients with SD should include x-rays of the vertebral column and MRI with contrast medium administration [112].

Radiographs. On X-rays, the combination of rapid loss of intervertebral disc height and adjacent lysis of bone is evocative of an infection. Progressive destruction of the vertebral body and the intervertebral disc becomes evident with the further spread of infection, and the process soon contaminates the adjacent vertebra [5].

Computed tomography. CT-guided needle biopsy is essential for diagnosis confirmation and isolation of the responsible microorganism [113,114].

Magnetic Resonance Imaging. MRI is the most used procedure in SD, having a sensitivity higher than 90\% [115]. Advantages include precise anatomical localization, early recognition of disc and bone destruction, the chance to perform multiplanar sequences, assessment of the bone marrow, and visualization of neural structures and soft tissues. However, it is limited by its low specificity because of false positive results in many cases such as in degenerative diseases, fractures by insufficiency, inflammatory processes, degenerative discal diseases with plate edema, vertebral amyloidosis, neuropathic arthropathy, and erosive intervertebral osteochondritis [116]. MRI is sensitive (up to 96\%) but lacks specificity in the presence of fractures or spinal implants. Differential diagnosis from erosive osteochondritis is often difficult.

Vertebral osteomyelitis can be noticed early by MRI (before evident alterations emerge on X-rays) [117]. Involvement of two adjacent vertebrae may be observed 1 to 3 weeks before radiographic or CT signs of bone destruction.

Typical MRI findings of SD include (1) hypointense vertebral bodies and disc with loss of endplate definition in T1-weighted images, (2) hyperintense vertebral bodies and disc with loss of endplate definition in T2-weighted images or STIR images, and (3) Gadolinium enhancement of the vertebral body and disc. Imaging must comprise the whole spine to assess the extension of SD and to exclude any adjacent or skip lesions [118]. Early extension of inflammatory edema outside the limits of the vertebral bodies and the annulus fibrosus into the paravertebral fat causes low signal intensity on T1-weighted SE non-contrast images and hyperintense postcontrast and STIR images.

Depending on the infectious germ, the MRI features can be different. MRI can help in differentiating tubercular from pyogenic spondylodiscitis. The detection of an intact anterior meningo-vertebral ligament in presence of an epidural abscess is associated with tuberculous spondylodiscitis rather than pyogenic ones [119]. The presence of an almost undamaged vertebra with a homogeneous high signal on T2WI is an important MRI feature to distinguish Brucella SD from tubercular ones [120].

DWI of the spine showed a good association with the presence/absence of spinal infection and can be complementary to standard MRI with additional information. Apparent diffusion coefficients (ADC) are significantly reduced in patients with positive microbiological sampling compared to those with negative ones [121].

Nuclear Medicine. Radionuclide imaging is a helpful additional exam to MRI. It is commonly used as a screening test, but false-negative results happen. The test is of no use for detecting soft-tissue infections which can be associated or mimic spinal OM. Bone scintigraphy with 99 Tc or LLS is not regularly suggested because of low sensitivity and specificity. Gallium scans can play a role because if the result is negative, OM is improbable. Fuster et al. [122] compared the combination of BS $+{ }_{67} \mathrm{Ga}$ scan with SPECT/CT and ${ }_{18 \mathrm{~F}} \mathrm{FDG}$ $\mathrm{PET} / \mathrm{CT}$ to diagnose SD and confirmed that they both provided comparable information. A metanalysis by Prodromou et al. [123] showed a sensitivity of $97 \%$ and a specificity of $88 \%$. The authors concluded that ${ }_{18 \mathrm{~F}} \mathrm{FDG}$ PET /CT is an exceptional instrument in case of suspicion of SD. False positive results are commonly due to post-surgical alterations, spinal metastases, or metallic implants. A further advantage of ${ }_{18 \mathrm{~F}} \mathrm{FDG}$ PET/CT is that it can be used both to assess response to therapy and to determine its length [124]. However, the test cannot discriminate infection from a tumor (Figure 5). Some studies revealed the superiority of ${ }_{18 \mathrm{~F}} \mathrm{FDG}$ PET/CT over MRI, especially to discern degenerative changes 
from SD and to diagnose low-grade SD $[125,126]$. The use of ${ }_{18 \mathrm{~F}} \mathrm{FDG}$ PET for diagnostic purposes is recommended in patients with a contraindication to MRI (due to metallic implants, pacemakers, or valve prostheses) or in nonconclusive MRI [127].

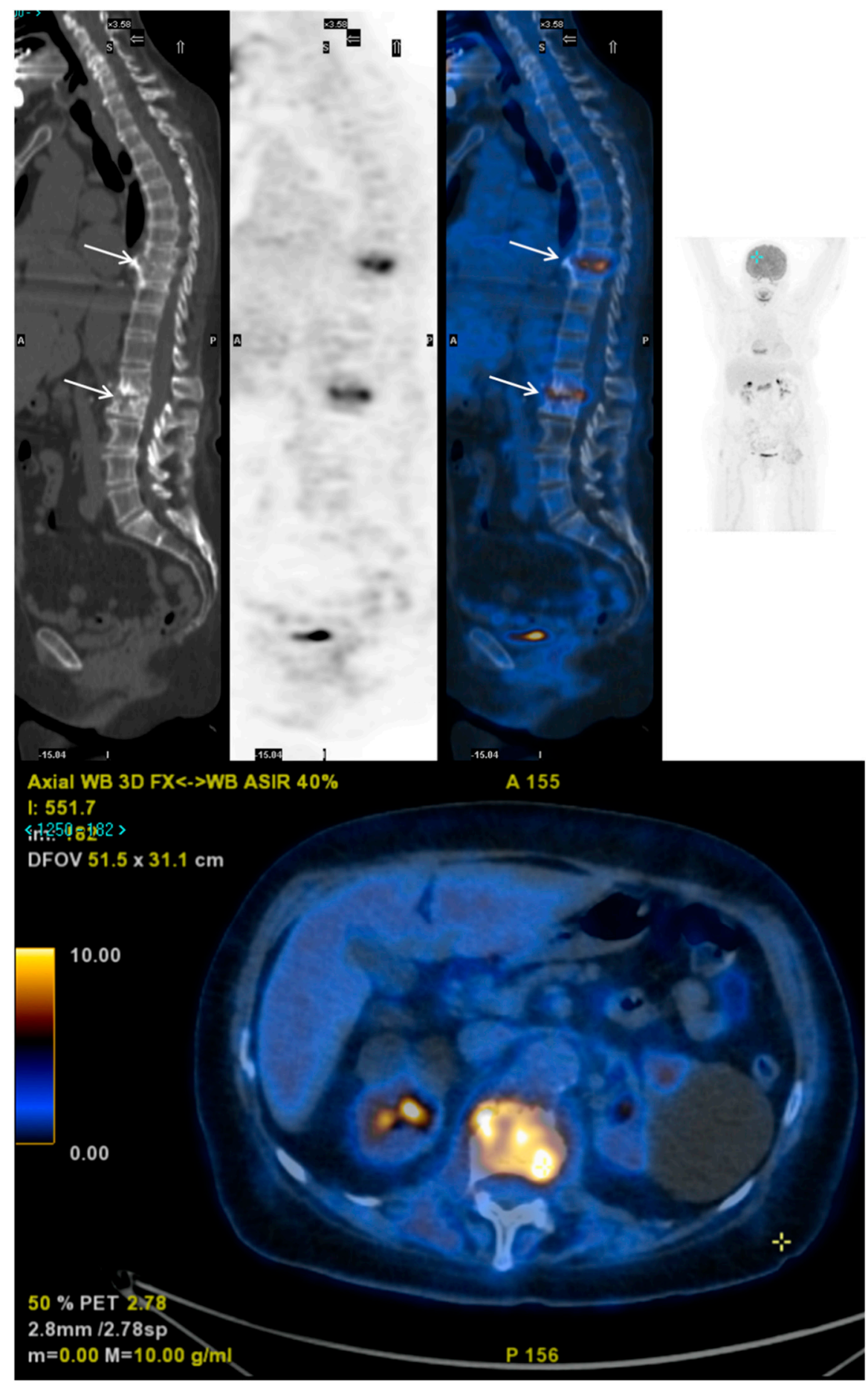

Figure 5. Pyogenic bifocal spondylodiscitis (T8-T9 and L1-L2) in a 70-year-old woman. FDG PET-CT showed increased SUV on both vertebral levels (arrows).

Newer tracers for BS such as indium-111 labeled (111 In) biotin and streptavidin have been recently presented, with high sensitivity, specificity, and diagnostic accuracy for spinal infections [128]. Other new tracers include the technetium Tc-99m-ubiquitin-derived peptide which has a high affinity to areas with viable bacterial growth, in addition to radiolabeled antifungal tracers to distinguish fungal from bacterial infections [129]. 


\section{Tuberculosis Arthritis}

Tuberculous (TB) spondylitis (Pott's disease) is the principal site of tuberculous bone involvement (approximately 50\% of cases) [130]. It usually involves the thoracic and, less often, the lumbar vertebral column [131].

Radiographs. X-rays are of low sensitivity for the initial diagnosis of Pott's disease. They identify vertebral involvement after at least $50 \%$ of a vertebra is damaged. Osteolytic lesions are more frequent than in pyogenic SD. Granulation tissue erodes and destroys cartilage and ultimately bone; areas of cartilage damage can be mixed with moderately normal zones.

Computed tomography. Thin-slice collimation spiral CT with multiplanar reconstruction can help in evaluating the damage of cancellous bone and deformity of the vertebral column in chronic cases (gibbus formation). Endplate destruction in tuberculous spondylitis often results in a more fragmented appearance than commonly observed with pyogenic organisms [132]. Spinal tuberculosis usually originates at the anteroinferior side of the vertebral body and extends to adjacent vertebrae along the anterior longitudinal ligament. Involvement of the posterior elements is rare but characteristic of $\mathrm{TB}$, not found in pyogenic SD $[133,134]$.

Magnetic Resonance Imaging MRI is superior to CT in the evaluation and follow-up on spondylitis [131]. Bone marrow alterations are non-specific and include a patchy high signal on T2-weighted and a low signal on T1-weighted images (Figure 6) [135]. Pott's disease has a minor amount of marrow edema than SD [136]. Hypointense T2-weighted image (secondary to areas of caseation) is associated with soft tissue abscesses [137]. Both involved vertebral disc and vertebral body have a similar signal intensity. However, disc involvement happens delayed than in SD, because of the lack of proteolytic destructive enzymes. T1-weighted images show intense enhancement after gadolinium administration.

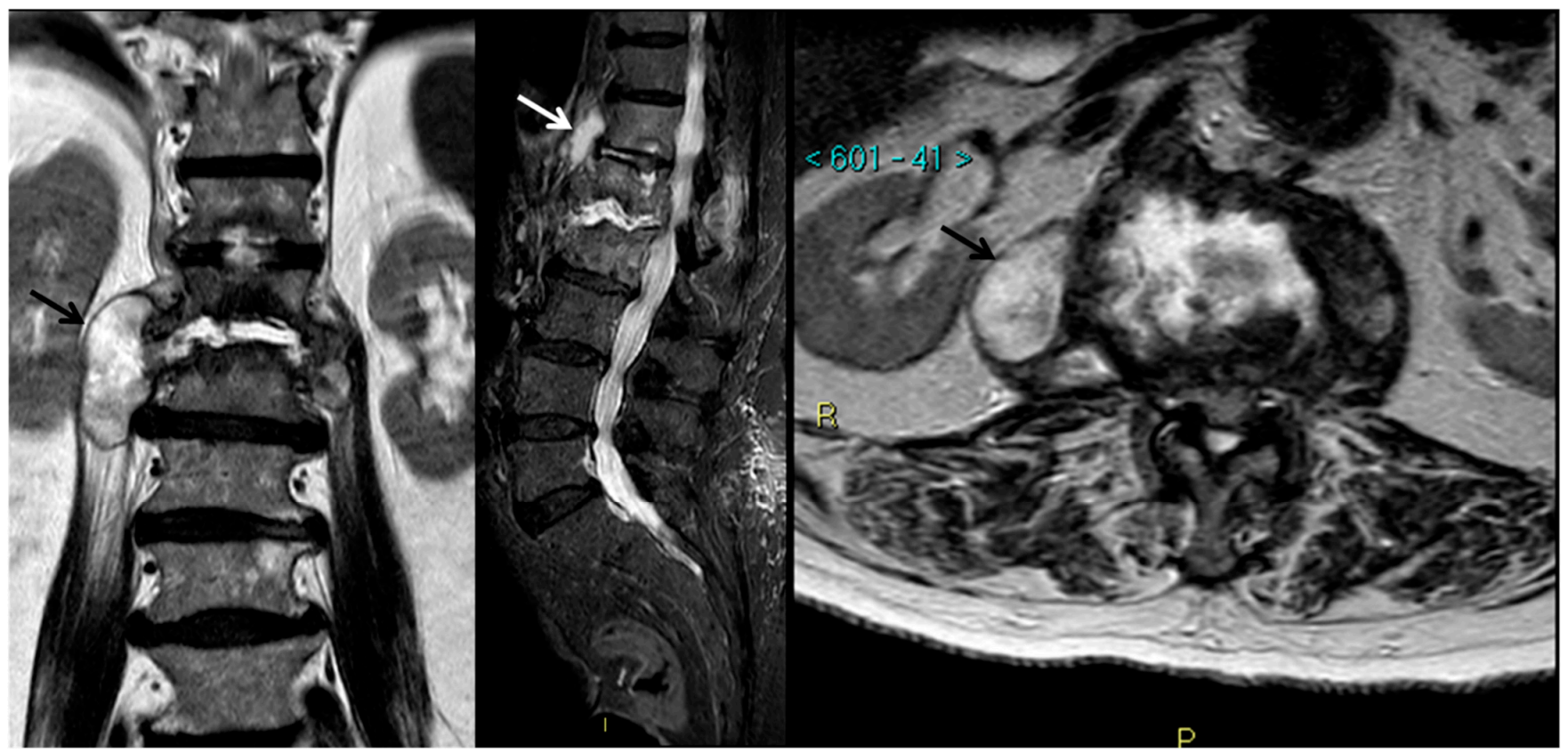

Figure 6. Tuberculous spondylodiscitis (T12-L2) in an 84-year-old woman. MRI detects bone and disks involvement together with several voluminous paravertebral abscesses (arrows).

TB spondylitis is strongly suggested in case of a slowly progressive vertebral process with preservation of intervertebral discs, the subligamentous spread of infection with erosion of anterior vertebral margins, large and calcified soft tissue abscesses, and the absence of severe bony eburnation [138]. 


\section{Chronic Recurrent Multifocal Osteomyelitis}

Chronic recurrent multifocal osteomyelitis (CRMO) is an autoimmune, non-infectious $\mathrm{OM}$ that usually occurs in children. It was also reported in adults, generally associated with synovitis, acne, pustulosis, hyperostosis, and osteitis [139]. It often affects the metaphysis of long bones, the pelvis, the spine, or the shoulder and clavicle [140,141].

CRMO remains a diagnosis of exclusion since there are no widely accepted diagnostic criteria and disease biomarkers. Imaging techniques are the mainstay for the diagnosis of CRMO [141].

Imaging findings of CRMO are analogous to hematogenous OM, with osteolysis surrounded by periostitis and soft tissue edema and subsequent progress of bony sclerosis. The presence of sequestra, sinus tracts, and soft tissue abscess is more suggestive of infective OM. Inflammatory bone lesions may be observed on x-rays as radiolucent, osteolytic, or sclerotic lesions, particularly in late stages [142]. Involvement of the medial portion of the clavicle and symmetric bilateral lesions in a patient without known malignancy is very suggestive of CRMO.

MRI is highly sensitive in particular in the initial phases (Figure 7). MRI is very sensitive for the early findings of CRMO, but even with MRI, the findings of marrow edema on T2 or short-tau inversion recovery (STIR) sequences are not specific [139]. MRI is important for the assessment of disease activity during follow-up [143]. Strongly T2-weighted sequences and/or gadolinium-enhanced T1 sequences with fat saturation are helpful for the identification of inflammatory bone lesions and/or periosseous affections [144,145].

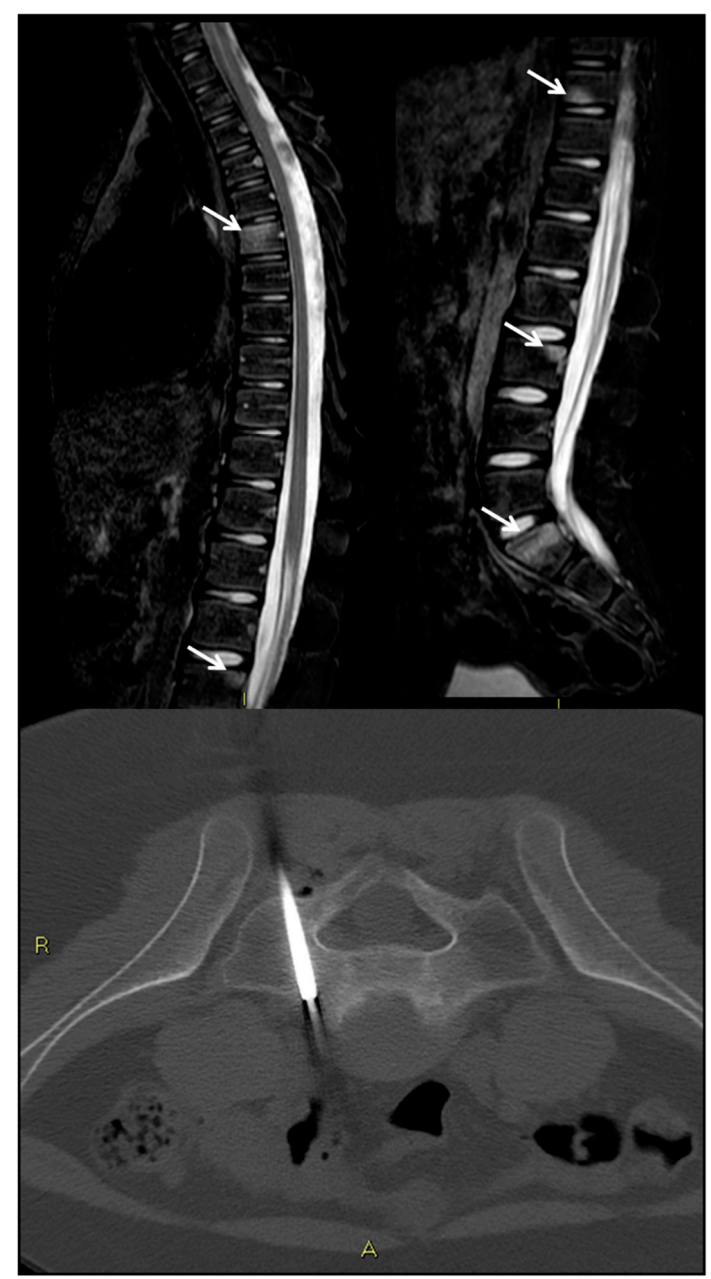

Figure 7. Chronic recurrent multifocal osteomyelitis (CRMO) in an 11-year-old boy. MRI shows several areas of bone edema in thoracic, lumbar, and sacral vertebral bodies (arrows). After a CT-guided bone biopsy of $\mathrm{S1}$, the diagnosis of exclusion was CRMO. 
CRMO is generally multifocal, although they often present with just a single site of pain. Whole-body (WB) imaging can identify additional asymptomatic or minimally symptomatic lesions, aiding in reaching the diagnosis of CRMO [143,146,147]. In the case of children with CRMO, it is important to have a relatively short scan time to eliminate or at least minimize the need for sedation. A full-sequence WB-MRI may take 4-6 h, which is not realistically feasible in children. STIR sequences are relatively fast sequences that are sensitive to the marrow edema seen in CRMO [144]. Many CRMO WB-MRI imaging protocols include STIR sequences only, while others also include diffusion and/or T1weighted imaging [148]. Compared to WB-MRI, bone scans require radiation and have decreased sensitivity, spatial resolution, and limited ability to evaluate physeal disease. Thus, WB-MRI is superior to bone scan in delineating the extent of disease.

\section{Conclusions}

We acknowledge that this is a narrative review of the literature, with inherent biases, including no critical appraisal of the quality of included studies in a systematic manner. Osteoarticular infection must be differentiated above all from malignant tumors but also from some benign tumors and pseudo-tumors. The clinical and laboratory panels sometimes cannot discriminate and the diagnosis can only be obtained on histological analysis. Thus, delays in treatment and inadequate management can frequently occur.

Bone and joint infections are a very heterogeneous group of diseases in terms of both affected site and severity. In general, conventional radiographs of the affected site should be performed as the first imaging examination (Table 1).

Table 1. A multidisciplinary team (MDT) evaluation which includes radiologist, orthopedic surgeon, infectious disease specialist, and microbiologist is essential for a correct diagnosis of infection.

\begin{tabular}{|c|c|c|c|c|c|}
\hline & X-Ray & Ultrasonography & CT-Scan & MRI & Nuclear Medicine \\
\hline Acute Osteomyelitis & $\begin{array}{ll}\text { - } & \text { low sensitivity } \\
\text { during the first } \\
\text { 10-14 days } \\
\text { cortical bone } \\
\text { destruction, } \\
\text { marrow } \\
\text { - } \\
\text { lucency } \\
\text { periosteal } \\
\text { reaction soft } \\
\text { tissues } \\
\text { alterations }\end{array}$ & $\begin{array}{ll}\text { - } & \text { juxtacortical } \\
\text { swelling of soft } \\
\text { tissues } \\
\text { periosteal } \\
\text { elevation or } \\
\text { thickening } \\
\text { possible } \\
\text { abscess } \\
\text { useful in } \\
\text { US-guided } \\
\text { biopsy }\end{array}$ & $\begin{array}{ll}- & \text { cortical erosion } \\
- & \text { foci of gas } \\
- & \text { soft tissue } \\
& \text { alterations } \\
\text { - } & \text { sinus tracts }\end{array}$ & $\begin{array}{l}\text { highly sensitive in } \\
\text { the first 3-5 days } \\
\text { medullary edema } \\
\text { and exudates } \\
\text { - } \quad \text { zones of necrosis } \\
\text { soft tissue } \\
\text { alterations/abscess }\end{array}$ & $\begin{array}{ll}\text { - } & \text { 3-phase } 99 \mathrm{mTc} B S: \\
& \text { high negative } \\
\text { predictive value } \\
\text { - } \\
\text { LLS + SPECT/CT: } \\
\text { method of choice in } \\
\text { patients with a } \\
\text { recent fracture or } \\
\text { recent surgery } \\
\text { 18FGD PET/CT: } \\
\text { useful in multifocal } \\
\text { osteomyelitis and } \\
\text { differential } \\
\text { diagnosis with } \\
\text { tumors } \\
\text { 18F-NaF PET/CT } \\
\text { recently proposed }\end{array}$ \\
\hline Septic Arthritis & $\begin{array}{ll}\text { - } & \text { bone erosions } \\
\text { - } & \text { joint space loss } \\
\text { periarticular } \\
\text { osteopenia } \\
\text { soft tissue } \\
\text { swelling } \\
\text { acute OM signs } \\
\text { on both sides of } \\
\text { the joint }\end{array}$ & $\begin{array}{ll}\text { - } & \text { joint effusion: } \\
\text { high sensitivity, } \\
\text { low specificity } \\
\text { power doppler: } \\
\text { synovial and } \\
\text { soft tissue } \\
\text { hyperemia } \\
\text { useful in } \\
\text { US-guided } \\
\text { joint aspiration }\end{array}$ & $\begin{array}{l}-\quad \text { joint effusion } \\
\text { acute OM signs on } \\
\text { both sides of the } \\
\text { joint }\end{array}$ & $\begin{array}{ll}- & \text { joint effusion } \\
- & \text { enhancing synovitis } \\
- & \text { cartilage thinning } \\
-\quad & \text { periarticular soft } \\
\text { tissue edema } & \text { subperiosteal fluid } \\
\text { collection }\end{array}$ & $\begin{array}{l}\text { 3-phase 99mTc BS: } \\
\text { useful in } \\
\text { differentiate OM } \\
\text { from soft-tissue } \\
\text { infection and in } \\
\text { multifocal joint } \\
\text { infections } \\
\text { 18FDG PET: low } \\
\text { specificity }\end{array}$ \\
\hline $\begin{array}{c}\text { Chronic } \\
\text { Osteomyelitis }\end{array}$ & $\begin{array}{l}\text { - } \\
\text { corterosis and } \\
\text { thickening } \\
\text { adjacent to lytic } \\
\text { zones within } \\
\text { the marrow }\end{array}$ & $\begin{array}{l}\text { useful in case } \\
\text { of } \\
\text { recrudescence } \\
\text { with acute OM } \\
\text { signs }\end{array}$ & $\begin{array}{l}\text { - } \\
\text { cclerosis and } \\
\text { cortical thickening } \\
\text { invasion of the } \\
\text { medullary cavity } \\
\text { - } \quad \text { sequestrum } \\
\text { useful in CT-guided } \\
\text { biopsy }\end{array}$ & $\begin{array}{ll}- & \text { sequestrum } \\
\text { - } & \text { cloaca } \\
- & \text { periostitis } \\
& \text { fibrovascular scar } \\
& \text { useful in } \\
\text { differentiate acute } \\
\text { from chronic OM }\end{array}$ & $\begin{array}{l}\text { 18FDG PET/CT: } \\
\text { high sensitivity and } \\
\text { specificity }\end{array}$ \\
\hline
\end{tabular}


Table 1. Cont.

\begin{tabular}{|c|c|c|c|c|c|}
\hline & X-Ray & Ultrasonography & CT-Scan & MRI & Nuclear Medicine \\
\hline Brodie's abscess & $\begin{array}{l}\text { usually, lytic } \\
\text { unicameral or } \\
\text { multiloculated } \\
\text { lesion with a } \\
\text { sclerotic rim }\end{array}$ & $\begin{array}{ll}\text { - } & \text { not routinary } \\
\text { used in } \\
\text { diagnosis }\end{array}$ & $\begin{array}{ll}\text { - } & \text { lytic lesion with a } \\
\text { sclerotic rim } \\
\text { - } \quad \text { well-circumscribed } \\
\text { periosteal reaction } \\
\text { - } \quad \begin{array}{l}\text { useful in CT-guided } \\
\text { biopsy }\end{array}\end{array}$ & $\begin{array}{l}\text { - } \quad \text { "target sign" } \\
\text { peripheral ring } \\
\text { contrast } \\
\text { enhancement }\end{array}$ & $\begin{array}{l}\text { - } \quad \text { scintigraphy } \\
\text { generally positive } \\
\text { 18FDG PET: unclear } \\
\text { role }\end{array}$ \\
\hline $\begin{array}{l}\text { Diabetic foot } \\
\text { osteomyelitis }\end{array}$ & $\begin{array}{ll}- & \text { foci of air } \\
-\quad & \text { cortical erosion } \\
\text { focal } \\
\text { osteopenia }\end{array}$ & $\begin{array}{ll}\text { - } & \text { not routinary } \\
\text { used in } \\
\text { diagnosis }\end{array}$ & $\begin{array}{ll}- & \text { periosteal reaction } \\
- & \text { cortical erosion } \\
- & \text { cortical loss } \\
\text { - } & \text { changes in bone } \\
& \text { marrow density }\end{array}$ & $\begin{array}{l}\text { - variable acute and } \\
\text { chronic OM signs }\end{array}$ & $\begin{array}{l}\text { WBC PET/CT } \\
\text { useful in diagnosis }\end{array}$ \\
\hline Prosthetic Infections & $\begin{array}{ll}- & \text { sclerosis } \\
- & \text { periosteal } \\
& \text { reaction } \\
\text { - } & \text { cortical } \\
& \text { thickening } \\
-\quad & \text { soft tissue gas } \\
\text { - } & \text { component } \\
\text { loosening }\end{array}$ & $\begin{array}{ll}\text { - } & \text { distention of } \\
\text { the } \\
\text { pseudocapsule } \\
\text { - } \quad \text { extracapsular } \\
\text { fluid collection } \\
\text { - } \quad \text { sinus tracts } \\
\text { useful in } \\
\text { US-guided } \\
\text { joint aspiration }\end{array}$ & 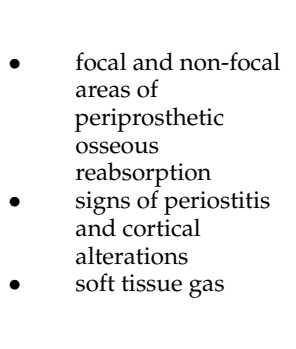 & $\begin{array}{ll}\text { - } & \text { pericapsular soft } \\
\text { tissue edema } \\
\text { - } \quad \text { extracapsular } \\
\text { collections } \\
\text { - } \quad \text { bone destruction } \\
\text { reactive } \\
\text { lymphadenopathy, } \\
\text { - } \quad \text { joint effusion } \\
\text { thick or lamellated } \\
\text { synovium }\end{array}$ & $\begin{array}{l}\text { LLS + SPECT/CT: } \\
\text { method of choice in } \\
\text { patients with a } \\
\text { recent fracture or } \\
\text { recent surgery } \\
\text { 18FDG-PET/CT: } \\
\text { higher sensitivity } \\
\text { but lower specificity } \\
\text { than LLS, must be } \\
\text { avoided for } 3 \text { to } 6 \\
\text { months after } \\
\text { surgery or trauma }\end{array}$ \\
\hline $\begin{array}{c}\text { Fracture related } \\
\text { infection }\end{array}$ & 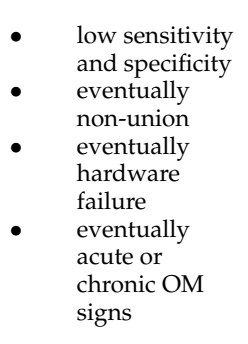 & $\begin{array}{ll}\text { - } & \text { not routinary } \\
\text { used in } \\
\text { diagnosis } \\
\text { eventually } \\
\text { acute or } \\
\text { chronic OM } \\
\text { signs }\end{array}$ & $\begin{array}{ll}\text { - } & \text { eventually } \\
\text { non-union } \\
\text { eventually } \\
\text { - } \quad \text { hardware failure } \\
\text { eventually acute or } \\
\text { chronic OM signs }\end{array}$ & $\begin{array}{l}\text { - } \quad \text { eventually acute or } \\
\text { chronic OM signs }\end{array}$ & $\begin{array}{l}\text { 3-phase 99mTc BS: } \\
\text { high sensitivity, low } \\
\text { specificity } \\
\text { LLS + SPECT/CT: } \\
\text { method of choice } \\
\text { for diagnosis } \\
\text { 18FDG-PET/CT: } \\
\text { high sensitivity and } \\
\text { specificity, simpler } \\
\text { method, useful in } \\
\text { patients on } \\
\text { antibiotic therapy }\end{array}$ \\
\hline
\end{tabular}

Spondylodiscitis

- $\quad$ low sensitivity deformity not routinary
used in

used in
- $\quad$ vertebral body deformity

- $\quad$ endplate

destruction

- $\quad$ useful in CT-guided biopsy
- $\quad$ most used imaging

technique

- $\quad$ high sensitivity, low specificity

- $\quad$ useful from 1 to 3 weeks before radiographic or $\mathrm{CT}$ signs

- $\quad$ T1-W hypointense/T2-WI hyperintense vertebral bodies and disc

- $\quad$ loss of endplate definition

- $\quad$ high contrast enhancement 3-phase 99mTc BS and LLS: low sensitivity and specificity 67Ga SPECT/TC and 18FDG PET: high sensitivity and specificity

- $\quad$ new tracers for PET may increase sensitivity and specificity$$
\text { . }
$$ 
Table 1. Cont.

\begin{tabular}{cllll}
\hline & X-ray & CT-Scan & Ultrasonography & MRI \\
\hline $\begin{array}{c}\text { Chronic recurrent } \\
\text { multifocal } \\
\text { osteomyelitis }\end{array}$ & $\bullet$ & $\begin{array}{l}\text { X-ray, US, CT-scan are analogous to infective OM } \\
\text { sequestra, sinus tracts, abscess are less frequent } \\
\text { often symmetrical distribution (clavicles often involved) } \\
\text { more frequent in children }\end{array}$ & $\begin{array}{l}\text { scintigraphy less } \\
\text { sensitive/specific } \\
\text { than whole body }\end{array}$ & $\begin{array}{l}\text { whole body STIR } \\
\text { sequences useful in } \\
\text { diagnosis }\end{array}$ \\
\end{tabular}

Second-line tests should be decided on a case-by-case basis by the MDT, according to clinical suspicion, type of BJI, site affected, and patient's characteristics, to reach an accurate diagnosis as soon as possible. Thus, these cases should be referred to multispecialty centers with all diagnostic tools. Recently, Sconfienza et al. proposed a flowchart that may guide the diagnosis of osteomyelitis and PJI [149].

New technologies such as PET/MRI are strongly emerging research platforms in imaging science [150] which might help in the diagnosis of bone infections. However, hybrid PET/MRI scanners are very expensive. Therefore, it seems preferable to use MRI as a primary imaging tool for uncomplicated unifocal cases, whereas in cases with (possible) multifocal disease or a contraindication for MRI, PET would be preferred.

Severe morbidity or mortality have been reported in BJI such as acute paraplegia in spine infections [151,152], severe and irreversible joint destruction and even death in septic arthritis [153], and sepsis and death in PJI [154].

However, no previous series reported on the possible consequences if the diagnosis is established late and the treatment is inadequate. However, the experience of the COVID-19 pandemic recently suggested that a delayed diagnostic process of disseminated invasive infections can increase the risk of fatal consequences, in particular in frail patients [155].

Therefore, an accurate and prompt diagnosis requires a high index of suspicion followed by the combination of adequate surgical and conservative treatment to prevent severe morbidity and decrease the risk of mortality.

Author Contributions: Conceptualization: A.S., S.T. and P.S.; investigation: E.Z., M.F. and R.Z.; writing-original draft preparation, A.S., P.S., S.T., C.G. and E.C.; writing-review and editing, A.C., P.V. and M.D.P.; supervision, P.V. and M.D.P. All authors have read and agreed to the published version of the manuscript.

Funding: This research received no external funding.

Institutional Review Board Statement: Not applicable.

Informed Consent Statement: Not applicable.

Data Availability Statement: Not applicable.

Conflicts of Interest: The authors declare no conflict of interest.

\section{References}

1. Kremers, H.M.; Nwojo, M.E.; Ransom, J.E.; Wood-Wentz, C.M.; Melton, L.J.; Huddleston, P.M. Trends in the epidemiology of osteomyelitis: A population-based study, 1969 to 2009. J. Bone Jt. Surg. Am. 2015, 97, 837-845. [CrossRef]

2. Malizos, K.N. Global Forum: The Burden of Bone and Joint Infections: A Growing Demand for More Resources. J. Bone Jt. Surg. Am. 2017, 99, e20. [CrossRef]

3. Laurent, E.; Gras, G.; Druon, J.; Rosset, P.; Baron, S.; Le-Louarn, A.; Rusch, E.; Bernard, L.; Grammatico-Guillon, L. Key features of bone and joint infections following the implementation of reference centers in France. Med. Mal. Infect. 2018, 48, 256-262. [CrossRef] [PubMed]

4. Sanders, J.; Mauffrey, C. Long bone osteomyelitis in adults: Fundamental concepts and current techniques. Orthopedics 2013, 36, 368-375. [CrossRef]

5. Pineda, C.; Vargas, A.; Rodríguez, A.V. Imaging of osteomyelitis: Current concepts. Infect. Dis. Clin. N. Am. 2006, 20, 789-825. [CrossRef]

6. Beaman, F.D.; von Herrmann, P.F.; Kransdorf, M.J.; Adler, R.S.; Amini, B.; Appel, M.; Arnold, E.; Bernard, S.A.; Greenspan, B.S.; Lee, K.S.; et al. ACR Appropriateness Criteria. J. Am. Coll. Radiol. 2017, 14, S326-S337. [CrossRef] [PubMed] 
7. Anwer, U.; Yablon, C.M. Imaging of Osteomyelitis of the Extremities. Semin. Roentgenol. 2017, 52, 49-54. [CrossRef] [PubMed]

8. Pineda, C.; Espinosa, R.; Pena, A. Radiographic imaging in osteomyelitis: The role of plain radiography, computed tomography, ultrasonography, magnetic resonance imaging, and scintigraphy. Semin. Plast. Surg. 2009, 23, 80-89. [CrossRef]

9. Noriega-Âlvarez, E.; Domínguez Gadea, L.; Orduña Diez, M.P.; Peiró Valgañón, V.; Sanz Viedma, S.; García Jiménez, R. Role of Nuclear Medicine in the diagnosis of musculoskeletal infection: A review. Rev. Esp. Med. Nucl. Imagen. Mol. 2019, 38, 397-407. [CrossRef]

10. Riebel, T.W.; Nasir, R.; Nazarenko, O. The value of sonography in the detection of osteomyelitis. Pediatr. Radiol. 1996, 26, 291-297. [CrossRef]

11. Howard, C.B.; Einhorn, M.; Dagan, R.; Nyska, M. Ultrasound in diagnosis and management of acute haematogenous osteomyelitis in children. J. Bone Jt. Surg. Br. 1993, 75, 79-82. [CrossRef] [PubMed]

12. Blickman, J.G.; van Die, C.E.; de Rooy, J.W. Current imaging concepts in pediatric osteomyelitis. Eur. Radiol. 2004, 14 (Suppl. 4), L55-L64. [CrossRef]

13. Ram, P.C.; Martinez, S.; Korobkin, M.; Breiman, R.S.; Gallis, H.R.; Harrelson, J.M. CT detection of intraosseous gas: A new sign of osteomyelitis. AJR Am. J. Roentgenol. 1981, 137, 721-723. [CrossRef]

14. Spaeth, H.J.; Chandnani, V.P.; Beltran, J.; Lucas, J.G.; Ortiz, I.; King, M.A.; Bennett, W.F.; Bova, J.G.; Mueller, C.F.; Shaffer, P.B. Magnetic resonance imaging detection of early experimental periostitis. Comparison of magnetic resonance imaging, computed tomography, and plain radiography with histopathologic correlation. Investig. Radiol. 1991, 26, 304-308. [CrossRef] [PubMed]

15. Kocher, M.S.; Lee, B.; Dolan, M.; Weinberg, J.; Shulman, S.T. Pediatric orthopedic infections: Early detection and treatment. Pediatr Ann. 2006, 35, 112-122. [CrossRef] [PubMed]

16. Boutin, R.D.; Brossmann, J.; Sartoris, D.J.; Reilly, D.; Resnick, D. Update on imaging of orthopedic infections. Orthop. Clin. N. Am. 1998, 29, 41-66. [CrossRef]

17. Collins, M.S.; Schaar, M.M.; Wenger, D.E.; Mandrekar, J.N. T1-weighted MRI characteristics of pedal osteomyelitis. AJR Am. J. Roentgenol. 2005, 185, 386-393. [CrossRef]

18. Kaplan, S.L. Osteomyelitis in children. Infect. Dis. Clin. N. Am. 2005, 19, 787-797. [CrossRef]

19. Calhoun, J.H.; Manring, M.M. Adult osteomyelitis. Infect. Dis. Clin. N. Am. 2005, 19, 765-786. [CrossRef]

20. Vilanova, J.C.; García-Figueiras, R.; Luna, A.; Baleato-González, S.; Tomás, X.; Narváez, J.A. Update on Whole-body MRI in Musculoskeletal Applications. Semin. Musculoskelet. Radiol. 2019, 23, 312-323. [CrossRef]

21. Koh, D.M.; Blackledge, M.; Padhani, A.R.; Takahara, T.; Kwee, T.C.; Leach, M.O.; Collins, D.J. Whole-body diffusion-weighted MRI: Tips, tricks, and pitfalls. AJR Am. J. Roentgenol. 2012, 199, 252-262. [CrossRef]

22. Sistrom, C.L.; McKay, N.L. Costs, charges, and revenues for hospital diagnostic imaging procedures: Differences by modality and hospital characteristics. J. Am. Coll. Radiol. 2005, 2, 511-519. [CrossRef] [PubMed]

23. Naraghi, A.M.; White, L.M. Magnetic resonance imaging of joint replacements. Semin. Musculoskelet. Radiol. 2006, 10, 98-106. [CrossRef] [PubMed]

24. Lee, E.M.; Ibrahim, E.H.; Dudek, N.; Lu, J.C.; Kalia, V.; Runge, M.; Srinivasan, A.; Stojanovska, J.; Agarwal, P.P. Improving MR Image Quality in Patients with Metallic Implants. Radiographics 2021, 41, E126-E137. [CrossRef] [PubMed]

25. Maurer, A.H.; Chen, D.C.; Camargo, E.E.; Wong, D.F.; Wagner, H.N.; Alderson, P.O. Utility of three-phase skeletal scintigraphy in suspected osteomyelitis: Concise communication. J. Nucl. Med. 1981, 22, 941-949.

26. Wang, G.L.; Zhao, K.; Liu, Z.F.; Dong, M.J.; Yang, S.Y. A meta-analysis of fluorodeoxyglucose-positron emission tomography versus scintigraphy in the evaluation of suspected osteomyelitis. Nucl. Med. Commun. 2011, 32, 1134-1142. [CrossRef]

27. Tumeh, S.S.; Aliabadi, P.; Weissman, B.N.; McNeil, B.J. Chronic osteomyelitis: Bone and gallium scan patterns associated with active disease. Radiology 1986, 158, 685-688. [CrossRef] [PubMed]

28. Glaudemans, A.W.J.M.; Jutte, P.C.; Cataldo, M.A.; Cassar-Pullicino, V.; Gheysens, O.; Borens, O.; Trampuz, A.; Wörtler, K.; Petrosillo, N.; Winkler, H.; et al. Consensus document for the diagnosis of peripheral bone infection in adults: A joint paper by the EANM, EBJIS, and ESR (with ESCMID endorsement). Eur. J. Nucl. Med. Mol. Imaging 2019, 46, 957-970. [CrossRef]

29. Palestro, C.J.; Love, C.; Bhargava, K.K. Labeled leukocyte imaging: Current status and future directions. Q J. Nucl. Med. Mol. Imaging 2009, 53, 105-123.

30. Love, C.; Palestro, C.J. Nuclear medicine imaging of bone infections. Clin. Radiol. 2016, 71, 632-646. [CrossRef]

31. Li, Y.; Wang, Q.; Wang, X.; Li, X.; Wu, H.; Yao, Z.; Miao, W.; Zhu, X.; Hua, F.; Zhang, X.; et al. Expert Consensus on clinical application of FDG PET/CT in infection and inflammation. Ann. Nucl. Med. 2020, 34, 369-376. [CrossRef] [PubMed]

32. Palestro, C.J.; Glaudemans, A.W.J.M.; Dierckx, R.A.J.O. Multiagent imaging of inflammation and infection with radionuclides. Clin. Transl. Imaging 2013, 1, 385-396. [CrossRef]

33. Beheshti, M.; Mottaghy, F.M.; Paycha, F.; Behrendt, F.F.F.; Van den Wyngaert, T.; Fogelman, I.; Strobel, K.; Celli, M.; Fanti, S.; Giammarile, F.; et al. (18)F-NaF PET/CT: EANM procedure guidelines for bone imaging. Eur. J. Nucl. Med. Mol. Imaging 2015, 42, 1767-1777. [CrossRef] [PubMed]

34. Schwegler, B.; Stumpe, K.D.; Weishaupt, D.; Strobel, K.; Spinas, G.A.; von Schulthess, G.K.; Hodler, J.; Böni, T.; Donath, M.Y. Unsuspected osteomyelitis is frequent in persistent diabetic foot ulcer and better diagnosed by MRI than by 18F-FDG PET or 99mTc-MOAB. J. Intern. Med. 2008, 263, 99-106. [CrossRef]

35. Gold, R.H.; Hawkins, R.A.; Katz, R.D. Bacterial osteomyelitis: Findings on plain radiography, CT, MR, and scintigraphy. AJR Am. J. Roentgenol. 1991, 157, 365-370. [CrossRef] [PubMed] 
36. Stumpe, K.D.; Zanetti, M.; Weishaupt, D.; Hodler, J.; Boos, N.; Von Schulthess, G.K. FDG positron emission tomography for differentiation of degenerative and infectious endplate abnormalities in the lumbar spine detected on MR imaging. AJR Am. J. Roentgenol. 2002, 179, 1151-1157. [CrossRef]

37. Demirev, A.; Weijers, R.; Geurts, J.; Mottaghy, F.; Walenkamp, G.; Brans, B. Comparison of [18 F]FDG PET/CT and MRI in the diagnosis of active osteomyelitis. Skeletal. Radiol. 2014, 43, 665-672. [CrossRef]

38. Zawin, J.K.; Hoffer, F.A.; Rand, F.F.; Teele, R.L. Joint effusion in children with an irritable hip: US diagnosis and aspiration. Radiology 1993, 187, 459-463. [CrossRef]

39. Strouse, P.J.; DiPietro, M.A.; Adler, R.S. Pediatric hip effusions: Evaluation with power Doppler sonography. Radiology 1998, 206, 731-735. [CrossRef]

40. Graif, M.; Schweitzer, M.E.; Deely, D.; Matteucci, T. The septic versus nonseptic inflamed joint: MRI characteristics. Skeletal. Radiol. 1999, 28, 616-620. [CrossRef]

41. Karchevsky, M.; Schweitzer, M.E.; Morrison, W.B.; Parellada, J.A. MRI findings of septic arthritis and associated osteomyelitis in adults. AJR Am. J. Roentgenol. 2004, 182, 119-122. [CrossRef]

42. Stumpe, K.D.; Strobel, K. Osteomyelitis and arthritis. Semin. Nucl. Med. 2009, 39, 27-35. [CrossRef]

43. Gholamrezanezhad, A.; Basques, K.; Batouli, A.; Matcuk, G.; Alavi, A.; Jadvar, H. Clinical Nononcologic Applications of PET/CT and PET/MRI in Musculoskeletal, Orthopedic, and Rheumatologic Imaging. AJR Am. J. Roentgenol. 2018, 210, W245-W263. [CrossRef] [PubMed]

44. Mouzopoulos, G.; Kanakaris, N.K.; Kontakis, G.; Obakponovwe, O.; Townsend, R.; Giannoudis, P.V. Management of bone infections in adults: The surgeon's and microbiologist's perspectives. Injury 2011, 42 (Suppl. 5), S18-S23. [CrossRef]

45. Chau, C.L.; Griffith, J.F. Musculoskeletal infections: Ultrasound appearances. Clin. Radiol. 2005, 60, 149-159. [CrossRef]

46. Wu, Y.; Lu, X.; Hong, J.; Lin, W.; Chen, S.; Mou, S.; Feng, G.; Yan, R.; Cheng, Z. Detection of extremity chronic traumatic osteomyelitis by machine learning based on computed-tomography images: A retrospective study. Medicine (Baltimore) 2020, 99, e19239. [CrossRef] [PubMed]

47. Abernethy, L.J.; Carty, H. Modern approach to the diagnosis of osteomyelitis in children. Br. J. Hosp. Med. 1997, 58, 464-468.

48. Kaim, A.H.; Gross, T.; von Schulthess, G.K. Imaging of chronic posttraumatic osteomyelitis. Eur. Radiol. 2002, 12, 1193-1202. [CrossRef] [PubMed]

49. Luchs, J.S.; Hines, J.; Katz, D.S.; Athanasian, E.A. MR imaging of squamous cell carcinoma complicating chronic osteomyelitis of the femur. AJR Am. J. Roentgenol. 2002, 178, 512-513. [CrossRef]

50. Guhlmann, A.; Brecht-Krauss, D.; Suger, G.; Glatting, G.; Kotzerke, J.; Kinzl, L.; Reske, S.N. Fluorine-18-FDG PET and technetium99m antigranulocyte antibody scintigraphy in chronic osteomyelitis. J. Nucl. Med. 1998, 39, 2145-2152.

51. Hartmann, A.; Eid, K.; Dora, C.; Trentz, O.; von Schulthess, G.K.; Stumpe, K.D.M. Diagnostic value of 18F-FDG PET/CT in trauma patients with suspected chronic osteomyelitis. Eur. J. Nucl. Med. Mol. Imaging 2007, 34, 704-714. [CrossRef] [PubMed]

52. Harris, N.H.; Kirkaldy-Willis, W.H. Primary subacute pyogenic osteomyelitis. J. Bone Jt. Surg. Br. 1965, 47, 526-532. [CrossRef]

53. Bohndorf, K. Infection of the appendicular skeleton. Eur. Radiol. 2004, 14 (Suppl. 3), E53-E63. [CrossRef]

54. Pöyhiä, T.; Azouz, E.M. MR imaging evaluation of subacute and chronic bone abscesses in children. Pediatr. Radiol. 2000, 30, 763-768. [CrossRef]

55. Martí-Bonmatí, L.; Aparisi, F.; Poyatos, C.; Vilar, J. Brodie abscess: MR imaging appearance in 10 patients. J. Magn. Reson. Imaging 1993, 3, 543-546. [CrossRef]

56. Strobel, K.; Hany, T.F.; Exner, G.U. PET/CT of a brodie abscess. Clin. Nucl. Med. 2006, 31, 210. [CrossRef]

57. Fathinul, F.; Nordin, A. F-FDG PET/CT as a potential valuable adjunct to MRI in characterising the Brodie's abscess. Biomed. Imaging Interv. J. 2010, 6, e26. [CrossRef] [PubMed]

58. Zhang, P.; Lu, J.; Jing, Y.; Tang, S.; Zhu, D.; Bi, Y. Global epidemiology of diabetic foot ulceration: A systematic review and meta-analysis. Ann. Med. 2017, 49, 106-116. [CrossRef] [PubMed]

59. Donovan, A.; Schweitzer, M.E. Use of MR imaging in diagnosing diabetes-related pedal osteomyelitis. Radiographics 2010, 30, 723-736. [CrossRef]

60. Basu, S.; Zhuang, H.; Alavi, A. FDG PET and PET/CT Imaging in Complicated Diabetic Foot. PET Clin. 2012, 7, 151-160. [CrossRef] [PubMed]

61. Grayson, M.L.; Gibbons, G.W.; Balogh, K.; Levin, E.; Karchmer, A.W. Probing to bone in infected pedal ulcers. A clinical sign of underlying osteomyelitis in diabetic patients. JAMA 1995, 273, 721-723. [CrossRef] [PubMed]

62. Palestro, C.J. Radionuclide Imaging of Musculoskeletal Infection: A Review. J. Nucl. Med. 2016, 57, 1406-1412. [CrossRef]

63. La Fontaine, J.; Bhavan, K.; Jupiter, D.; Lavery, L.A.; Chhabra, A. Magnetic Resonance Imaging of Diabetic Foot Osteomyelitis: Imaging Accuracy in Biopsy-Proven Disease. J. Foot Ankle Surg. 2021, 60, 17-20. [CrossRef] [PubMed]

64. Lipsky, B.A.; Berendt, A.R.; Cornia, P.B.; Pile, J.C.; Peters, E.J.; Armstrong, D.G.; Deery, H.G.; Embil, J.M.; Joseph, W.S.; Karchmer, A.W.; et al. 2012 Infectious Diseases Society of America clinical practice guideline for the diagnosis and treatment of diabetic foot infections. Clin. Infect. Dis. 2012, 54, e132-e173. [CrossRef] [PubMed]

65. Dinh, M.T.; Abad, C.L.; Safdar, N. Diagnostic accuracy of the physical examination and imaging tests for osteomyelitis underlying diabetic foot ulcers: Meta-analysis. Clin. Infect. Dis. 2008, 47, 519-527. [CrossRef]

66. Baker, J.C.; Demertzis, J.L.; Rhodes, N.G.; Wessell, D.E.; Rubin, D.A. Diabetic musculoskeletal complications and their imaging mimics. Radiographics 2012, 32, 1959-1974. [CrossRef] 
67. Chatha, D.S.; Cunningham, P.M.; Schweitzer, M.E. MR imaging of the diabetic foot: Diagnostic challenges. Radiol. Clin. N. Am. 2005, 43, 747-759. [CrossRef]

68. Morrison, W.B.; Schweitzer, M.E.; Batte, W.G.; Radack, D.P.; Russel, K.M. Osteomyelitis of the foot: Relative importance of primary and secondary MR imaging signs. Radiology 1998, 207, 625-632. [CrossRef]

69. Duryea, D.; Bernard, S.; Flemming, D.; Walker, E.; French, C. Outcomes in diabetic foot ulcer patients with isolated T2 marrow signal abnormality in the underlying bone: Should the diagnosis of "osteitis" be changed to "early osteomyelitis"? Skeletal. Radiol. 2017, 46, 1327-1333. [CrossRef]

70. Treglia, G.; Sadeghi, R.; Annunziata, S.; Zakavi, S.R.; Caldarella, C.; Muoio, B.; Bertagna, F.; Ceriani, L.; Giovanella, L. Diagnostic performance of Fluorine-18-Fluorodeoxyglucose positron emission tomography for the diagnosis of osteomyelitis related to diabetic foot: A systematic review and a meta-analysis. Foot (Edinb) 2013, 23, 140-148. [CrossRef]

71. Palestro, C.J.; Love, C. Nuclear medicine and diabetic foot infections. Semin. Nucl. Med. 2009, 39, 52-65. [CrossRef] [PubMed]

72. Palestro, C.J. 18F-FDG and diabetic foot infections: The verdict is. J. Nucl. Med. 2011, 52, 1009-1011. [CrossRef]

73. Jaramillo, D.; Treves, S.T.; Kasser, J.R.; Harper, M.; Sundel, R.; Laor, T. Osteomyelitis and septic arthritis in children: Appropriate use of imaging to guide treatment. AJR Am. J. Roentgenol. 1995, 165, 399-403. [CrossRef] [PubMed]

74. Signore, A.; Sconfienza, L.M.; Borens, O.; Glaudemans, A.W.J.M.; Cassar-Pullicino, V.; Trampuz, A.; Winkler, H.; Gheysens, O.; Vanhoenacker, F.M.H.M.; Petrosillo, N.; et al. Consensus document for the diagnosis of prosthetic joint infections: A joint paper by the EANM, EBJIS, and ESR (with ESCMID endorsement). Eur. J. Nucl. Med. Mol. Imaging 2019, 46, 971-988. [CrossRef]

75. Cyteval, C.; Hamm, V.; Sarrabère, M.P.; Lopez, F.M.; Maury, P.; Taourel, P. Painful infection at the site of hip prosthesis: CT imaging. Radiology 2002, 224, 477-483. [CrossRef]

76. Rabin, D.N.; Smith, C.; Kubicka, R.A.; Rabin, S.; Ali, A.; Charters, J.R.; Rabin, H. Problem prostheses: The radiologic evaluation of total joint replacement. Radiographics 1987, 7, 1107-1127. [CrossRef] [PubMed]

77. Fritz, J.; Lurie, B.; Miller, T.T.; Potter, H.G. MR imaging of hip arthroplasty implants. Radiographics 2014, 34, E106-E132. [CrossRef] [PubMed]

78. van Holsbeeck, M.T.; Eyler, W.R.; Sherman, L.S.; Lombardi, T.J.; Mezger, E.; Verner, J.J.; Schurman, J.R.; Jonsson, K. Detection of infection in loosened hip prostheses: Efficacy of sonography. AJR Am. J. Roentgenol. 1994, 163, 381-384. [CrossRef]

79. Weybright, P.N.; Jacobson, J.A.; Murry, K.H.; Lin, J.; Fessell, D.P.; Jamadar, D.A.; Kabeto, M.; Hayes, C.W. Limited effectiveness of sonography in revealing hip joint effusion: Preliminary results in 21 adult patients with native and postoperative hips. AJR Am. J. Roentgenol. 2003, 181, 215-218. [CrossRef]

80. Bureau, N.J.; Chhem, R.K.; Cardinal, E. Musculoskeletal infections: US manifestations. Radiographics 1999, 19, 1585-1592. [CrossRef]

81. Lohmann, C.H.; Rampal, S.; Lohrengel, M.; Singh, G. Imaging in peri-prosthetic assessment: An orthopaedic perspective. EFORT Open Rev. 2017, 2, 117-125. [CrossRef]

82. Isern-Kebschull, J.; Tomas, X.; García-Díez, A.I.; Morata, L.; Moya, I.; Ríos, J.; Soriano, A. Value of multidetector computed tomography for the differentiation of delayed aseptic and septic complications after total hip arthroplasty. Skeletal. Radiol. 2020, 49, 893-902. [CrossRef]

83. Talbot, B.S.; Weinberg, E.P. MR Imaging with Metal-suppression Sequences for Evaluation of Total Joint Arthroplasty. Radiographics 2016, 36, 209-225. [CrossRef]

84. Galley, J.; Sutter, R.; Stern, C.; Filli, L.; Rahm, S.; Pfirrmann, C.W.A. Diagnosis of Periprosthetic Hip Joint Infection Using MRI with Metal Artifact Reduction at 1.5 T. Radiology 2020, 296, 98-108. [CrossRef]

85. Jungmann, P.M.; Agten, C.A.; Pfirrmann, C.W.; Sutter, R. Advances in MRI around metal. J. Magn. Reson. Imaging 2017, 46, 972-991. [CrossRef]

86. Albano, D.; Messina, C.; Zagra, L.; Andreata, M.; De Vecchi, E.; Gitto, S.; Sconfienza, L.M. Failed Total Hip Arthroplasty: Diagnostic Performance of Conventional MRI Features and Locoregional Lymphadenopathy to Identify Infected Implants. J. Magn. Reson. Imaging 2021, 53, 201-210. [CrossRef]

87. Plodkowski, A.J.; Hayter, C.L.; Miller, T.T.; Nguyen, J.T.; Potter, H.G. Lamellated hyperintense synovitis: Potential MR imaging sign of an infected knee arthroplasty. Radiology 2013, 266, 256-260. [CrossRef] [PubMed]

88. Li, A.E.; Sneag, D.B.; Greditzer, H.G.; Johnson, C.C.; Miller, T.T.; Potter, H.G. Total Knee Arthroplasty: Diagnostic Accuracy of Patterns of Synovitis at MR Imaging. Radiology 2016, 281, 499-506. [CrossRef] [PubMed]

89. Gao, Z.; Jin, Y.; Chen, X.; Dai, Z.; Qiang, S.; Guan, S.; Li, Q.; Huang, J.; Zheng, J. Diagnostic Value of MRI Lamellated Hyperintense Synovitis in Periprosthetic Infection of Hip. Orthop. Surg. 2020, 12, 1941-1946. [CrossRef] [PubMed]

90. van der Bruggen, W.; Bleeker-Rovers, C.P.; Boerman, O.C.; Gotthardt, M.; Oyen, W.J. PET and SPECT in osteomyelitis and prosthetic bone and joint infections: A systematic review. Semin. Nucl. Med. 2010, 40, 3-15. [CrossRef]

91. Glaudemans, A.W.; de Vries, E.F.; Vermeulen, L.E.; Slart, R.H.; Dierckx, R.A.; Signore, A. A large retrospective single-centre study to define the best image acquisition protocols and interpretation criteria for white blood cell scintigraphy with ${ }^{99} \mathrm{mTc}-$ HMPAO-labelled leucocytes in musculoskeletal infections. Eur. J. Nucl. Med. Mol. Imaging 2013, 40, 1760-1769. [CrossRef] [PubMed]

92. Palestro, C.J. Nuclear medicine and the failed joint replacement: Past, present, and future. World J. Radiol. 2014, 6, 446-458. [CrossRef] 
93. Tam, H.H.; Bhaludin, B.; Rahman, F.; Weller, A.; Ejindu, V.; Parthipun, A. SPECT-CT in total hip arthroplasty. Clin. Radiol. 2014, 69, 82-95. [CrossRef]

94. Mandegaran, R.; Agrawal, K.; Vijayanathan, S.; Gnanasegaran, G. The value of 99mTc-MDP bone SPECT/CT in evaluation of patients with painful knee prosthesis. Nucl. Med. Commun. 2018, 39, 397-404. [CrossRef] [PubMed]

95. Chacko, T.K.; Zhuang, H.; Stevenson, K.; Moussavian, B.; Alavi, A. The importance of the location of fluorodeoxyglucose uptake in periprosthetic infection in painful hip prostheses. Nucl. Med. Commun. 2002, 23, 851-855. [CrossRef]

96. Vanquickenborne, B.; Maes, A.; Nuyts, J.; Van Acker, F.; Stuyck, J.; Mulier, M.; Verbruggen, A.; Mortelmans, L. The value of (18)FDG-PET for the detection of infected hip prosthesis. Eur. J. Nucl. Med. Mol. Imaging 2003, 30, 705-715. [CrossRef] [PubMed]

97. Reinartz, P.; Mumme, T.; Hermanns, B.; Cremerius, U.; Wirtz, D.C.; Schaefer, W.M.; Niethard, F.; Buell, U. Radionuclide imaging of the painful hip arthroplasty: Positron-emission tomography versus triple-phase bone scanning. J. Bone Jt. Surg. Br. 2005, 87, 465-470. [CrossRef]

98. Rubin, R.H.; Fischman, A.J. The use of radiolabeled nonspecific immunoglobulin in the detection of focal inflammation. Semin. Nucl. Med. 1994, 24, 169-179. [CrossRef]

99. Jamar, F.; Buscombe, J.; Chiti, A.; Christian, P.E.; Delbeke, D.; Donohoe, K.J.; Israel, O.; Martin-Comin, J.; Signore, A. EANM/SNMMI guideline for 18F-FDG use in inflammation and infection. J. Nucl. Med. 2013, 54, 647-658. [CrossRef]

100. Metsemakers, W.J.; Morgenstern, M.; McNally, M.A.; Moriarty, T.F.; McFadyen, I.; Scarborough, M.; Athanasou, N.A.; Ochsner, P.E.; Kuehl, R.; Raschke, M.; et al. Fracture-related infection: A consensus on definition from an international expert group. Injury 2018, 49, 505-510. [CrossRef] [PubMed]

101. McNally, M.; Govaert, G.; Dudareva, M.; Morgenstern, M.; Metsemakers, W.J. Definition and diagnosis of fracture-related infection. EFORT Open Rev. 2020, 5, 614-619. [CrossRef] [PubMed]

102. Lee, Y.J.; Sadigh, S.; Mankad, K.; Kapse, N.; Rajeswaran, G. The imaging of osteomyelitis. Quant. Imaging Med. Surg. 2016, 6, 184-198. [CrossRef]

103. Bühne, K.H.; Bohndorf, K. Imaging of posttraumatic osteomyelitis. Semin. Musculoskelet. Radiol. 2004, 8, 199-204. [CrossRef] [PubMed]

104. Govaert, G.A.; IJpma, F.F.; McNally, M.; McNally, E.; Reininga, I.H.; Glaudemans, A.W. Accuracy of diagnostic imaging modalities for peripheral post-traumatic osteomyelitis-a systematic review of the recent literature. Eur. J. Nucl. Med. Mol. Imaging 2017, 44, 1393-1407. [CrossRef] [PubMed]

105. Gupta, A.; Subhas, N.; Primak, A.N.; Nittka, M.; Liu, K. Metal artifact reduction: Standard and advanced magnetic resonance and computed tomography techniques. Radiol. Clin. N. Am. 2015, 53, 531-547. [CrossRef] [PubMed]

106. Govaert, G.A.M.; Glaudemans, A.W.J.M. Nuclear medicine imaging of posttraumatic osteomyelitis. Eur. J. Trauma Emerg. Surg. 2016, 42, 397-410. [CrossRef]

107. Wenter, V.; Müller, J.P.; Albert, N.L.; Lehner, S.; Fendler, W.P.; Bartenstein, P.; Cyran, C.C.; Friederichs, J.; Militz, M.; Hacker, M.; et al. The diagnostic value of [(18)F]FDG PET for the detection of chronic osteomyelitis and implant-associated infection. Eur. J. Nucl. Med. Mol. Imaging 2016, 43, 749-761. [CrossRef]

108. Kumar, R.; Basu, S.; Torigian, D.; Anand, V.; Zhuang, H.; Alavi, A. Role of modern imaging techniques for diagnosis of infection in the era of 18F-fluorodeoxyglucose positron emission tomography. Clin. Microbiol. Rev. 2008, 21, 209-224. [CrossRef]

109. Lemans, J.V.C.; Hobbelink, M.G.G.; IJpma, F.F.A.; Plate, J.D.J.; van den Kieboom, J.; Bosch, P.; Leenen, L.P.H.; Kruyt, M.C.; Glaudemans, A.W.J.M.; Govaert, G.A.M. The diagnostic accuracy of. Eur. J. Nucl. Med. Mol. Imaging 2019, 46, 999-1008. [CrossRef] [PubMed]

110. Govaert, G.A.M.; Glaudemans, A.W.J.M.; Ploegmakers, J.J.W.; Viddeleer, A.R.; Wendt, K.W.; Reininga, I.H.F. Diagnostic strategies for posttraumatic osteomyelitis: A survey amongst Dutch medical specialists demonstrates the need for a consensus protocol. Eur. J. Trauma Emerg. Surg. 2018, 44, 417-426. [CrossRef] [PubMed]

111. Michel, S.C.; Pfirrmann, C.W.; Boos, N.; Hodler, J. CT-guided core biopsy of subchondral bone and intervertebral space in suspected spondylodiskitis. AJR Am. J. Roentgenol. 2006, 186, 977-980. [CrossRef] [PubMed]

112. Lew, D.P.; Waldvogel, F.A. Osteomyelitis. Lancet 2004, 364, 369-379. [CrossRef]

113. Rimondi, E.; Rossi, G.; Bartalena, T.; Ciminari, R.; Alberghini, M.; Ruggieri, P.; Errani, C.; Angelini, A.; Calabrò, T.; Abati, C.N.; et al. Percutaneous CT-guided biopsy of the musculoskeletal system: Results of 2027 cases. Eur. J. Radiol. 2011, 77, 34-42. [CrossRef]

114. Kim, C.J.; Song, K.H.; Park, W.B.; Kim, E.S.; Park, S.W.; Kim, H.B.; Oh, M.D.; Kim, N.J. Microbiologically and clinically diagnosed vertebral osteomyelitis: Impact of prior antibiotic exposure. Antimicrob. Agents Chemother. 2012, 56, 2122-2124. [CrossRef] [PubMed]

115. Jevtic, V. Vertebral infection. Eur. Radiol. 2004, 14 (Suppl. 3), E43-E52. [CrossRef]

116. Morales, H. Infectious Spondylitis Mimics: Mechanisms of Disease and Imaging Findings. Semin. Ultrasound CT MR 2018, 39, 587-604. [CrossRef] [PubMed]

117. Karwowska, A.; Davies, H.D.; Jadavji, T. Epidemiology and outcome of osteomyelitis in the era of sequential intravenous-oral therapy. Pediatr. Infect. Dis. J. 1998, 17, 1021-1026. [CrossRef]

118. Ledermann, H.P.; Morrison, W.B.; Schweitzer, M.E. MR image analysis of pedal osteomyelitis: Distribution, patterns of spread, and frequency of associated ulceration and septic arthritis. Radiology 2002, 223, 747-755. [CrossRef] 
119. Strauss, S.B.; Gordon, S.R.; Burns, J.; Bello, J.A.; Slasky, S.E. Differentiation between Tuberculous and Pyogenic Spondylodiscitis: The Role of the Anterior Meningovertebral Ligament in Patients with Anterior Epidural Abscess. AJNR Am. J. Neuroradiol. 2020, 41, 364-368. [CrossRef]

120. Liu, X.; Li, H.; Jin, C.; Niu, G.; Guo, B.; Chen, Y.; Yang, J. Differentiation Between Brucellar and Tuberculous Spondylodiscitis in the Acute and Subacute Stages by MRI: A Retrospective Observational Study. Acad Radiol. 2018, 25, 1183-1189. [CrossRef] [PubMed]

121. Dumont, R.A.; Keen, N.N.; Bloomer, C.W.; Schwartz, B.S.; Talbott, J.; Clark, A.J.; Wilson, D.M.; Chin, C.T. Clinical Utility of Diffusion-Weighted Imaging in Spinal Infections. Clin. Neuroradiol. 2019, 29, 515-522. [CrossRef] [PubMed]

122. Fuster, D.; Solà, O.; Soriano, A.; Monegal, A.; Setoain, X.; Tomás, X.; Garcia, S.; Mensa, J.; Rubello, D.; Pons, F. A prospective study comparing whole-body FDG PET/CT to combined planar bone scan with 67Ga SPECT/CT in the Diagnosis of Spondylodiskitis. Clin. Nucl. Med. 2012, 37, 827-832. [CrossRef] [PubMed]

123. Prodromou, M.L.; Ziakas, P.D.; Poulou, L.S.; Karsaliakos, P.; Thanos, L.; Mylonakis, E. FDG PET is a robust tool for the diagnosis of spondylodiscitis: A meta-analysis of diagnostic data. Clin. Nucl. Med. 2014, 39, 330-335. [CrossRef] [PubMed]

124. Nanni, C.; Boriani, L.; Salvadori, C.; Zamparini, E.; Rorato, G.; Ambrosini, V.; Gasbarrini, A.; Tumietto, F.; Cristini, F.; Scudeller, L.; et al. FDG PET/CT is useful for the interim evaluation of response to therapy in patients affected by haematogenous spondylodiscitis. Eur. J. Nucl. Med. Mol. Imaging 2012, 39, 1538-1544. [CrossRef]

125. Kim, S.J.; Pak, K.; Kim, K.; Lee, J.S. Comparing the Diagnostic Accuracies of F-18 Fluorodeoxyglucose Positron Emission Tomography and Magnetic Resonance Imaging for the Detection of Spondylodiscitis: A Meta-analysis. Spine (Phila Pa 1976) 2019, 44, E414-E422. [CrossRef] [PubMed]

126. Yin, Y.; Liu, X.; Yang, X.; Guo, J.; Wang, Q.; Chen, L. Diagnostic value of FDG-PET versus magnetic resonance imaging for detecting spondylitis: A systematic review and meta-analysis. Spine J. 2018, 18, 2323-2332. [CrossRef] [PubMed]

127. Berbari, E.F.; Kanj, S.S.; Kowalski, T.J.; Darouiche, R.O.; Widmer, A.F.; Schmitt, S.K.; Hendershot, E.F.; Holtom, P.D.; Huddleston, P.M.; Petermann, G.W.; et al. 2015 Infectious Diseases Society of America (IDSA) Clinical Practice Guidelines for the Diagnosis and Treatment of Native Vertebral Osteomyelitis in Adults. Clin. Infect. Dis. 2015, 61, e26-e46. [CrossRef] [PubMed]

128. Lazzeri, E.; Pauwels, E.K.; Erba, P.A.; Volterrani, D.; Manca, M.; Bodei, L.; Trippi, D.; Bottoni, A.; Cristofani, R.; Consoli, V.; et al Clinical feasibility of two-step streptavidin/111In-biotin scintigraphy in patients with suspected vertebral osteomyelitis. Eur. J. Nucl. Med. Mol. Imaging 2004, 31, 1505-1511. [CrossRef]

129. Lupetti, A.; Welling, M.M.; Mazzi, U.; Nibbering, P.H.; Pauwels, E.K. Technetium-99m labelled fluconazole and antimicrobial peptides for imaging of Candida albicans and Aspergillus fumigatus infections. Eur. J. Nucl. Med. Mol. Imaging 2002, 29, 674-679. [CrossRef]

130. De Vuyst, D.; Vanhoenacker, F.; Gielen, J.; Bernaerts, A.; De Schepper, A.M. Imaging features of musculoskeletal tuberculosis. Eur. Radiol. 2003, 13, 1809-1819. [CrossRef]

131. Stäbler, A.; Reiser, M.F. Imaging of spinal infection. Radiol. Clin. N. Am. 2001, 39, 115-135. [CrossRef]

132. Sharif, H.S.; Morgan, J.L.; Al Shahed, M.S.; Al Thagafi, M.Y. Role of CT and MR imaging in the management of tuberculous spondylitis. Radiol. Clin. N. Am. 1995, 33, 787-804.

133. Ahmadi, J.; Bajaj, A.; Destian, S.; Segall, H.D.; Zee, C.S. Spinal tuberculosis: Atypical observations at MR imaging. Radiology 1993, 189, 489-493. [CrossRef] [PubMed]

134. Maiuri, F.; Iaconetta, G.; Gallicchio, B.; Manto, A.; Briganti, F. Spondylodiscitis. Clinical and magnetic resonance diagnosis. Spine (Phila Pa 1976) 1997, 22, 1741-1746. [CrossRef]

135. Ridley, N.; Shaikh, M.I.; Remedios, D.; Mitchell, R. Radiology of skeletal tuberculosis. Orthopedics 1998, 21, 1213-1220. [CrossRef] [PubMed]

136. Hong, S.H.; Kim, S.M.; Ahn, J.M.; Chung, H.W.; Shin, M.J.; Kang, H.S. Tuberculous versus pyogenic arthritis: MR imaging evaluation. Radiology 2001, 218, 848-853. [CrossRef]

137. Sharma, P. MR features of tuberculous osteomyelitis. Skeletal. Radiol. 2003, 32, 279-285. [CrossRef]

138. Naselli, N.; Facchini, G.; Lima, G.M.; Evangelisti, G.; Ponti, F.; Miceli, M.; Spinnato, P. MRI in differential diagnosis between tuberculous and pyogenic spondylodiscitis. Eur. Spine J. 2021. [CrossRef]

139. Khanna, G.; Sato, T.S.; Ferguson, P. Imaging of chronic recurrent multifocal osteomyelitis. Radiographics 2009, $29,1159-1177$. [CrossRef]

140. Borzutzky, A.; Stern, S.; Reiff, A.; Zurakowski, D.; Steinberg, E.A.; Dedeoglu, F.; Sundel, R.P. Pediatric chronic nonbacterial osteomyelitis. Pediatrics 2012, 130, e1190-e1197. [CrossRef]

141. Schnabel, A.; Range, U.; Hahn, G.; Siepmann, T.; Berner, R.; Hedrich, C.M. Unexpectedly high incidences of chronic non-bacterial as compared to bacterial osteomyelitis in children. Rheumatol. Int. 2016, 36, 1737-1745. [CrossRef] [PubMed]

142. Duffy, C.M.; Lam, P.Y.; Ditchfield, M.; Allen, R.; Graham, H.K. Chronic recurrent multifocal osteomyelitis: Review of orthopaedic complications at maturity. J. Pediatr. Orthop. 2002, 22, 501-505. [CrossRef]

143. Hofmann, C.; Wurm, M.; Schwarz, T.; Neubauer, H.; Beer, M.; Girschick, H.; Morbach, H. A standardized clinical and radiological follow-up of patients with chronic non-bacterial osteomyelitis treated with pamidronate. Clin. Exp. Rheumatol. 2014, 32, 604-609.

144. Jurik, A.G.; Egund, N. MRI in chronic recurrent multifocal osteomyelitis. Skeletal. Radiol. 1997, 26, 230-238. [CrossRef] 
145. Morbach, H.; Schneider, P.; Schwarz, T.; Hofmann, C.; Raab, P.; Neubauer, H.; Düren, C.; Beer, M.; Girschick, H.J. Comparison of magnetic resonance imaging and 99mTechnetium-labelled methylene diphosphonate bone scintigraphy in the initial assessment of chronic non-bacterial osteomyelitis of childhood and adolescents. Clin. Exp. Rheumatol. 2012, 30, 578-582. [PubMed]

146. Korchi, A.M.; Hanquinet, S.; Anooshiravani, M.; Merlini, L. Whole-body magnetic resonance imaging: An essential tool for diagnosis and work up of non-oncological systemic diseases in children. Minerva Pediatr. 2014, 66, 169-176.

147. Andronikou, S.; Kraft, J.K.; Offiah, A.C.; Jones, J.; Douis, H.; Thyagarajan, M.; Barrera, C.A.; Zouvani, A.; Ramanan, A.V. Whole-body MRI in the diagnosis of paediatric CNO/CRMO. Rheumatology (Oxford) 2020, 59, 2671-2680. [CrossRef] [PubMed]

148. Merlini, L.; Carpentier, M.; Ferrey, S.; Anooshiravani, M.; Poletti, P.A.; Hanquinet, S. Whole-body MRI in children: Would a 3D STIR sequence alone be sufficient for investigating common paediatric conditions? A comparative study. Eur. J. Radiol. 2017, 88, 155-162. [CrossRef]

149. Sconfienza, L.M.; Signore, A.; Cassar-Pullicino, V.; Cataldo, M.A.; Gheysens, O.; Borens, O.; Trampuz, A.; Wörtler, K.; Petrosillo, N.; Winkler, H.; et al. Diagnosis of peripheral bone and prosthetic joint infections: Overview on the consensus documents by the EANM, EBJIS, and ESR (with ESCMID endorsement). Eur. Radiol. 2019, 29, 6425-6438. [CrossRef]

150. Sollini, M.; Berchiolli, R.; Kirienko, M.; Rossi, A.; Glaudemans, A.W.J.M.; Slart, R.; Erba, P.A. PET/MRI in Infection and Inflammation. Semin. Nucl. Med. 2018, 48, 225-241. [CrossRef]

151. Turgut, M. Complete recovery of acute paraplegia due to pyogenic thoracic spondylodiscitis with an epidural abscess. Acta Neurochir. (Wien) 2008, 150, 381-386. [CrossRef]

152. Ferroir, J.P.; Lescure, F.X.; Giannesini, C.; Elghozi, D.; Marro, B. Paraplegia associated with intramedullary spinal cord and epidural abcesses, meningitis and spondylodiscitis (Staphylococcus aureus). Rev. Neurol. (Paris) 2012, 168, 868-872. [CrossRef] [PubMed]

153. Mathews, C.J.; Weston, V.C.; Jones, A.; Field, M.; Coakley, G. Bacterial septic arthritis in adults. Lancet 2010, $375,846-855$. [CrossRef]

154. Natsuhara, K.M.; Shelton, T.J.; Meehan, J.P.; Lum, Z.C. Mortality During Total Hip Periprosthetic Joint Infection. J. Arthroplast. 2019, 34, S337-S342. [CrossRef]

155. Westhovens, I.; Schalck, N.; Van Keerberghen, C.A.; Vanden Abeele, M.E. Delay in accurate diagnostics during the COVID-19 pandemic: A case of fatal MSSA disseminated infection in an elder patient. Tijdschr. Gerontol. Geriatr. 2021, 52. [CrossRef] 